\title{
36. NEOGENE BENTHIC FORAMINIFERS FROM THE SOUTHERN INDIAN OCEAN (KERGUELEN PLATEAU): BIOSTRATIGRAPHY AND PALEOECOLOGY1
}

\author{
Andreas Mackensen ${ }^{2}$
}

\begin{abstract}
Benthic foraminifers were studied quantitatively in 120 lower Miocene through upper Pleistocene samples from Ocean Drilling Program Site 747 (Central Kerguelen Plateau) and Sites 748 and 751 (Southern Kerguelen Plateau). These sites are situated on an $\approx 450$-km-long, north-south transect between $54^{\circ} 49^{\prime} \mathrm{S}$ and $58^{\circ} 26^{\prime} \mathrm{S}$ at present water depths between 1696 and $1288 \mathrm{~m}$. Principal component analysis on the census data of the most abundant 92 taxa helped to identify 8 benthic foraminifer assemblages. These benthic foraminifer assemblages were compared with Holocene faunas from southern high latitudes to reconstruct paleoenvironmental conditions.

Middle lower Miocene sediments are characterized by a Uvigerina hispidocostata assemblage, indicating high paleoproductivity and/or not well-ventilated bottom water. From late early to late middle Miocene time, the Southern Kerguelen Plateau was bathed by a young, well-oxygenated, and carbonate-aggressive water mass, as indicated by a Nuttallides umbonifer-dominated benthic foraminifer assemblage. During late middle Miocene time, an Astrononion pusillum assemblage took over for only about $1 \mathrm{~m} . \mathrm{y}$. , probably indicating the first injection of an aged water mass, similar to the North Atlantic Deep Water (NADW), into a developing circumpolar current system. Around the middle to late Miocene boundary, the fauna again became dominated by $N$. umbonifer. After the last appearance of $N$. umbonifer, reestablishment of the $A$. pusillum assemblage from the early late through at least the late late Miocene, indicated the established influence of a NADW-like water mass.

The latest Miocene through middle late Pliocene benthic foraminifer assemblage was characterized by Epistominella exigua and strong carbonate dissolution, indicating very high biosiliceous production, and this in turn may indicate the formation and paleoposition of an Antarctic Polar Frontal Zone. From the late late Pliocene, a Trifarina angulosa assemblage (indicative today of sandy substrate and vigorous bottom currents) strongly dominated the fauna up to the late Pleistocene, when Bulimina aculeata (indicative today of calm sedimentation with high organic matter fluxes) became an important and partly dominating constituent of the fauna. This is interpreted as the faunal response to the decreased winnowing force (bottom current velocities) of the Antarctic Circumpolar Current during periods of global climatic amelioration and raised sea level.
\end{abstract}

\section{INTRODUCTION}

On Ocean Drilling Program (ODP) Leg 120, we drilled three sites on the Kerguelen Plateau in the southern Indian Ocean: Site 747 (1696 m water depth; $54^{\circ} 48.68^{\prime} \mathrm{S}, 76^{\circ} 47.64^{\prime} \mathrm{E}$ ) on the Northern Kerguelen Plateau, and Sites 748 (1288 m water depth; $\left.58^{\circ} 26.45^{\prime} \mathrm{S}, 78^{\circ} 58.89^{\prime} \mathrm{E}\right)$ and 751 (1634 m present water depth; $57^{\circ} 43.56^{\prime} \mathrm{S}, 79^{\circ} 48.89^{\prime} \mathrm{E}$ ) on the Southern Kerguelen Plateau. These sites recovered 60-160-m-thick Neogene sections of foraminifer diatom oozes and diatom nannofossil oozes (Schlich, Wise, et al., 1989). Leg 120 was the last of four ODP legs around Antarctica $(113,114,119$, and 120) that had as one of their main objectives the reconstruction of the climatic changes during the Neogene history of the Earth.

Since the discovery that during peak cold climatic periods atmospheric $\mathrm{CO}_{2}$ concentration was about $30 \%$ below interglacial values (Barnola et al., 1987), understanding of the global carbon cycle in the late Neogene as well as during Tertiary time has been one of the major goals in paleoceanographic research. Redistribution of carbon within the ocean, the world's largest $\mathrm{CO}_{2}$ reservoir (Broecker and Peng, 1986), is an important influence on the global climate. Bottom-water circulation and biological productivity are two of the mechanisms responsible for the partitioning and the redistribution of carbon within the ocean.

\footnotetext{
${ }^{1}$ Wise, S. W., Jr., Schlich, R., et al., 1992. Proc. ODP, Sci. Results, 120: College Station, TX (Ocean Drilling Program).

2 Alfred Wegener Institute for Polar and Marine Research, P. O. Box 120161, D-2850 Bremerhaven, Federal Republic of Germany.
}

In the late Neogene, the Southern Ocean played a key role in controlling global paleoproductivity and bottom-water circulation. Either increased surface productivity in the Southern Ocean during cold climatic periods (Keir, 1988) or reduced productivity there (Mackensen et al., 1989; Grobe et al., 1990) with high productive zones at low latitudes (Mix, 1989) might have caused enhanced $\mathrm{CO}_{2}$ storage in the deep ocean (Sarnthein et al., 1988). Since early middle Miocene time, perhaps since the late Eocene (Thomas, 1990), but definitely, since the early late Miocene (Woodruff and Savin, 1989), the Southern Ocean has been one of the earth's principal sources of oceanic bottom-waters (Foster and Middleton, 1980; Foldvik et al., 1985), and changes in the rate and mode of bottom-water production causes changes in global ocean circulation patterns.

Calcareous and arenaceous benthic foraminifers are abundant and ubiquitous faunal constituents of deep-sea sediments, and record information on paleoproductivity and bottom-water circulation. Specific high productivity faunas are associated with upwelling zones and reflect high fluxes of particulate organic matter (Lutze and Coulbourn, 1984; Corliss and Chen, 1988). Other assemblages are associated with specific bottom-water mass characteristics and substrate conditions (Douglas and Woodruff, 1981; Mackensen et al., 1985, 1990) and can be used to infer bottom-water routes and distribution (Corliss, 1983; Mackensen and Hald, 1988).

Previous reports on Holocene benthic foraminifers from the era of the national expeditions into the Southern Ocean include Wiesner (1931), Heron-Allen and Earland (1932), Earland (1933, 1934, 1936), and Uchio (1960). More recent studies of benthic foraminifer distribution patterns and their 
physical and chemical environment include McKnight (1962), Echols (1971), Herb (1971), Anderson (1975), Osterman and Kellogg (1979), Corliss (1979, 1983), Milam and Anderson (1981), Lindenberg and Auras (1984), Mead and Kennett (1987), Mackensen and Douglas (1989), and Mackensen et al. (1990).

Investigations of benthic foraminifers from Neogene sections from south of the present-day Antarctic Convergence are from Rögl (1976), Leckie and Webb (1986) and Thomas (1990). I quantitatively examined benthic foraminifers from the Neogene sections of Leg 120 Sites 747, 748, and 751.

\section{OCEANOGRAPHIC SETTINGS}

The Antarctic Circumpolar Current (ACC) is driven eastward around Antarctica by prevailing westerly winds. The ACC-transport capacity today is estimated to be $130 \mathrm{~Sv}(\mathrm{~Sv}=$ Sverdrup $=10^{6} \mathrm{~m}^{3} / \mathrm{s}$ ) with an average velocity of $25-30 \mathrm{~cm} / \mathrm{s}$ at the surface and about $10 \mathrm{~cm} / \mathrm{s}$ at $3000 \mathrm{~m}$ water depth (Whitworth, 1988).

The Polar Front is the southern boundary of the Polar Frontal Zone, a transition zone where cold, less saline Antarctic surface water meets warmer, more saline subantarctic surface water. The northern boundary of the Polar Frontal Zone is called the Subantarctic Front. The Polar Front is on a circumpolar average situated at about $52^{\circ}$ to $53^{\circ} \mathrm{S}$ (Hellmer and Bersch, 1985). The position of the Polar Frontal Zone is important: because of its strong thermal gradients and the upwelling of deeper northern waters associated with the Polar Frontal Zone, it acts as a barrier for planktonic organisms and is also an area of high primary productivity.

However, at the Kerguelen Plateau, between Kerguelen and Heard Islands, the position of the major oceanographic boundaries are highly variable, and it is still under discussion whether there exists a subantarctic zone at all (the zone north of the Subantarctic Front) (Whitworth, 1988; Deacon, 1983). Differences in the productivity between the western and eastern sides of the Kerguelen Plateau have been attributed to upwelling on the eastern side (Plancke, 1977).

In the southern Indian Ocean, the Circumpolar Deep Water (CDW) is a mix between deep and bottom-waters from other regions. It accounts for two-thirds of the water masses driven by the ACC (Emery and Meincke, 1986). The CDW is composed of $45 \%$ Weddell Sea water, $30 \%$ Pacific and Indian ocean intermediate waters, and $25 \%$ deep water originating from the North Atlantic (Broecker et al., 1985).

The deepest of the water masses affected by the ACC is the Antarctic Bottom-water (AABW), which is mainly formed in the Weddell and Ross seas. The formation of AABW is either linked to large floating ice shelves, such as the Ronne and Ross ice shelves, and the super-cooling beneath them (Foldvik et al., 1985; Foldvik and Gammelsr $\varnothing$ d, 1988), or to polynyas kept open in front of the ice-shelf edges by katabatic winds, or a combination of both. For this study it is important to keep in mind that today the bathyal and abyssal water masses at the Kerguelen Plateau are more than $50 \%$ of Weddell Sea origin.

\section{METHODS}

\section{Samples and Raw Data}

Benthic foraminifers were studied quantitatively in $20-\mathrm{cm}^{3}$ samples taken from upper Pleistocene through lower Miocene sections from Holes 747A (11 samples; Table 1, on microfiche in backpocket) and 748B ( 21 samples; Table 2, on microfiche) as well as from all sections of Hole 751A (56 samples; Table 3, on microfiche), which ended in the lower Miocene (see Appendix A for a list of all benthic foraminifers included in the principal component analyses). In addition, an aliquot of unknown size of all core-catcher samples, taken from the Neogene cores of these sites was examined semiquantitatively (Hole 747A: 13 samples, Table 1; Hole 748B: 7 samples, Table 2; and Hole 751A: 13 samples, Table 3; Tables 1-3 on microfiche).

The samples were washed through a $63-\mu \mathrm{m}$ sieve and dried in an oven at $60^{\circ} \mathrm{C}$. The residue was dry sieved over a $125-\mu \mathrm{m}$ screen, and aliquots from the $>125-\mu \mathrm{m}$ fraction were picked and counted. About 300 specimens were picked when possible. The number of individuals of each species is listed in the sequence of first appearances (Tables 1-3, on microfiche).

For paleoecological reconstructions and for assistance in evaluating the major changes in faunal compositions, Q-mode principal component analysis (with subsequent Varimax rotation) was performed on the census data of all sites to reduce the benthic foraminifer raw data matrix ( 92 taxa $\times 138$ samples) to 8 principal components (PCs) that explain $82.8 \%$ of the total variance with communalities of $<0.4$ (Appendix B, on microfiche) for only $6 \%$ of the samples. Only species that occurred in at least two samples and with a relative abundance of $\geq 1 \%$ in at least one sample, and samples that contained $\geq 20$ specimens (Tables $1-3$, on microfiche) were used for statistical analysis (Appendix A). The Varimax principal component loadings (Appendix B, on microfiche) indicate how much any particular PC contributes in explaining the faunal assemblage of any particular sample. Consequently, the communality (sum of all squared loadings) gives a measure of how well the variance of any particular sample is explained by the suggested solution (i.e., all of the PCs). On the other hand, the squared loading of one particular PC of one sample indicates how much of the total variance (faunal diversity) of the reduced data set is explained by this particular PC (benthic foraminifer assemblage) in this particular sample (Figs. 1-7). The Varimax principal component scores (Appendix C, on microfiche) indicate the importance of any particular species within each of the principal components.

The principal components representing the uppermost Miocene and Pliocene-Pleistocene benthic foraminifer faunas were compared with almost identical Holocene assemblages from the eastern Weddell Sea continental margin, which were investigated using the same statistical methods (Mackensen et al., 1990).

\section{Stratigraphy and Paleodepth}

The age model used in this paper is preliminarily based on biostratigraphic and paleomagnetic data as outlined by the Shipboard Scientific Party (Schlich, Wise, et al., 1989) and Heider et al. (this volume). The modifications based on the reinterpretation of parts of the paleomagnetic record as proposed by Berggren (this volume) are included.

At the northern Site 747 from the Central Kerguelen Plateau (1696 m present water depth), the Neogene is about $128 \mathrm{~m}$ thick and is interrupted by only one short hiatus of about $2 \mathrm{~m} . \mathrm{y}$. across the Miocene/Pliocene boundary. At the more southern Site 751 from the Southern Kerguelen Plateau $(1634 \mathrm{~m})$, in addition to a short hiatus across the Miocene/ Pliocene boundary, two disconformities in the lower middle and the upper late Miocene, respectively, interrupted the sedimentary sequence. At the southernmost Site 748 from $1288 \mathrm{~m}$ water depth, a hiatus across the Miocene/Pliocene boundary, and at least two hiatuses within the Pliocene and Pleistocene are present. In addition, a hiatus estimated to span about $5 \mathrm{~m}$.y., separates the upper lower from the middle Miocene (Berggren, this volume).

Paleodepths for the sites cannot be estimated by backtracking because Kerguelen Plateau together with Broken Ridge forms a pair of aseismic ridges separated by the Southeast 
Indian Ridge (Schlich, Wise, et al., 1989, "Introduction" chapter). Consequently, the basaltic basement drilled at Sites 747 and 748 is not a typical Mid-Oceanic Ridge Basalt (MORB), but transitional between normal Indian Ocean MORB and Kerguelen and Heard island Oceanic-Island Basalt.

\section{RESULTS}

\section{Preservation}

Benthic foraminifers from sediments of Hole $747 \mathrm{~A}$ were generally well preserved and abundant in all samples, although they were rare in comparison with the planktonic component. In Hole 748B specimens in upper lower Pliocene samples were badly preserved, and some samples did not contain sufficient numbers of benthic foraminifers for statistical treatment (Table 2, on microfiche).

At Site 751 , benthic foraminifers were generally rare and poorly preserved in samples from the mud-line down to the upper Pliocene (Sample 120-751A-2H-3, 108-112 cm; $8.78 \mathrm{~m}$ below sea floor [mbsf]), although in most samples more than 100 specimens could be picked for quantitative analysis (Table 3 , on microfiche). The lower upper Pliocene through lower Pliocene sediments (Samples 120-751A-2H-4, 36-40 cm, through $-5 \mathrm{H}-5,72-76 \mathrm{~cm} ; 9.56-39.92 \mathrm{mbsf}$ ) did not contain sufficient numbers of benthic foraminifers for quantitative treatment. Except for Samples 120-751A-3H-4, 72-76 cm, $-3 \mathrm{H}-5,72-76 \mathrm{~cm}$, and $-4 \mathrm{H}-5,72-76 \mathrm{~cm}$, which contain a very poorly preserved calcareous benthic foraminifer fauna, all other samples of this interval include an almost monospecific arenaceous fauna dominated by Martinotiella nodulosa. The upper Miocene through upper middle Miocene benthic foraminifer faunas again have generally low diversity and are poorly preserved, but in all samples (Samples 120-751A$5 \mathrm{H}-5,108-112 \mathrm{~cm}$, through $-12 \mathrm{H}-4,72-76 \mathrm{~cm} ; 40.28-104.92$ mbsf) sufficient numbers for quantitative treatment have been counted. Benthic foraminifers of early middle and early Miocene age (Samples 120-751A-12H-6, 72-76 cm, through $-18 \mathrm{H}-\mathrm{CC}$; 107.92-166.20 mbsf) are abundant and well preserved.

\section{Faunal Composition}

The benthic foraminifer assemblages that follow were recognized in the Neogene sedimentary sequences of Holes $747 \mathrm{~A}, 748 \mathrm{~B}$, and 751A. These assemblages are named after their most characteristic species (instead of numbers representing a specific set of species) to keep the data presentation and the discussion as convenient as possible (i.e., a species name with the suffix "assemblage" includes a PC typified by this species, but the species name without "assemblage" just means the single species). The characteristic species does not in all cases need to be the dominant one; for example, the Uvigerina hispidocostata assemblage is defined by the cooccurrence of $N$. umbonifer and $U$. hispidocostata, but not by the dominance of $U$. hispidocostata. However, the characteristic species composition of each assemblage and the criteria for separation from the under- and overlying benthic foraminifer assemblages are given. In addition, all assemblages and their exact boundaries with ranges of uncertainty caused by sampling densities are summarized in Table 4 and Figure 10. The boundaries between assemblages are chosen according to the principal component loadings in combination with last and first appearances of indicative but sometimes rare species. Also, samples not used in the statistical analysis, are included for determining assemblage boundaries. Consequently, the assemblage boundaries (Tables 1-4) do not in all instances coincide exactly with the shift of loadings proposed by the statistical analyses (Appendixes B and C), which in Q-mode largely depends on the similarity of proportions within the samples.

\section{Uvigerina hispido-costata Assemblage (PC V): Middle Early Miocene}

In Hole 751A sediments, this assemblage occurs in nine samples from $120-751 \mathrm{~A}-18 \mathrm{H}-\mathrm{CC}$ (in $166.20 \mathrm{mbsf}$ where the hole ended), through $-15 \mathrm{H}-5,36-40 \mathrm{~cm}$ (134.56 mbsf). In Hole $747 \mathrm{~A}$ it was found in eight samples from $120-747 \mathrm{~A}-13 \mathrm{H}-2$, $72-76 \mathrm{~cm}$ (115.72 mbsf) through - $10 \mathrm{H}-\mathrm{CC}$ ( $94.50 \mathrm{mbsf})$, and in Hole $748 \mathrm{~B}$ in six samples from $120-748 \mathrm{~B}-8 \mathrm{H}-2,72-76 \mathrm{~cm}$ (59.32 mbsf) through $-6 \mathrm{H}-5,72-76 \mathrm{~cm}$ (44.82 mbsf) (Fig. 1). This benthic foraminifer assemblage is characterized by the co-occurrence of Uvigerina hispidocostata and N. umbonifer. Astrononion pusillum, Eggerella bradyi, and Pullenia bulloides are common accessory components. Globocassidulina subglobosa and Cibicidoides spp. are present in varying numbers. This assemblage accounts for $4.3 \%$ of the total variance in the reduced data set.

\section{Nuttallides umbonifer Assemblage (PC I): Late Early Miocene through Middle Middle Miocene and Early Late Miocene}

In the sedimentary sequence of Hole $751 \mathrm{~A}$, the $N$. umbonifer assemblage is represented by 22 samples between 137.70 and $95.42 \mathrm{mbsf}(120-751 \mathrm{~A}-15 \mathrm{H}-\mathrm{CC}$ through $-11 \mathrm{H}-4,72-76 \mathrm{~cm})$ and between 77.92 and 66.92 mbsf $(120-751 \mathrm{~A}-9 \mathrm{H}-5,72-76 \mathrm{~cm}$, through $-8 \mathrm{H}-4,72-76 \mathrm{~cm})$. In Hole $747 \mathrm{~A}$ this assemblage was found in 12 samples between 90.22 and 61.72 mbsf (120-747A$10 \mathrm{H}-4,72-76 \mathrm{~cm}$, through $-7 \mathrm{H}-4,72-76 \mathrm{~cm}$ ) and from 56.50 to $52.22 \mathrm{mbsf}(120-747 \mathrm{~A}-6 \mathrm{H}-\mathrm{CC}$ and $-6 \mathrm{H}-4,72-76 \mathrm{~cm})$. In Hole

Table 4. Benthic foraminifer assemblage boundaries in Holes 747 A, 748B, and 751A.

\begin{tabular}{|c|c|c|c|c|c|c|}
\hline \multirow{2}{*}{$\begin{array}{c}\text { Benthic } \\
\text { foraminifer } \\
\text { assemblage }\end{array}$} & \multicolumn{2}{|c|}{ Hole 747A } & \multicolumn{2}{|c|}{ Hole 748B } & \multicolumn{2}{|c|}{ Hole $751 \mathrm{~A}$} \\
\hline & $\begin{array}{l}\text { top sample } \\
\text { (mbsf) }\end{array}$ & $\begin{array}{c}\text { base sample } \\
\text { (mbsf) }\end{array}$ & $\begin{array}{l}\text { top sample } \\
\text { (mbsf) }\end{array}$ & $\begin{array}{c}\text { base sample } \\
\text { (mbsf) }\end{array}$ & $\begin{array}{l}\text { top sample } \\
\text { (mbsf) }\end{array}$ & $\begin{array}{c}\text { base sample } \\
\text { (mbsf) }\end{array}$ \\
\hline VIII & 0.25 & 5.22 & 0.10 & 0.10 & 0.00 & 2.32 \\
\hline II & 9.00 & 14.22 & 0.46 & 6.04 & 2.80 & 6.14 \\
\hline VII & & & 6.82 & 11.82 & & \\
\hline V I & & & 16.32 & 38.10 & & \\
\hline IV & 18.50 & 28.00 & & & 6.56 & 40.70 \\
\hline 111 & 30.22 & 49.22 & & & 42.70 & 66.92 \\
\hline I & 52.22 & 56.50 & & & 71.20 & 77.92 \\
\hline 111 & 58.72 & 58.72 & & & 80.70 & 92.42 \\
\hline 1 & 61.72 & 90.22 & 40.32 & 40.32 & 95.42 & 130.06 \\
\hline v & 94.50 & 115.72 & 44.82 & 59.32 & 134.56 & 166.20 \\
\hline
\end{tabular}

Notes: Data are given in mbsf between the top sample of an underlying assemblage and the base sample of an overlying assemblage. Assemblage boundaries may be diachronous between sites. 


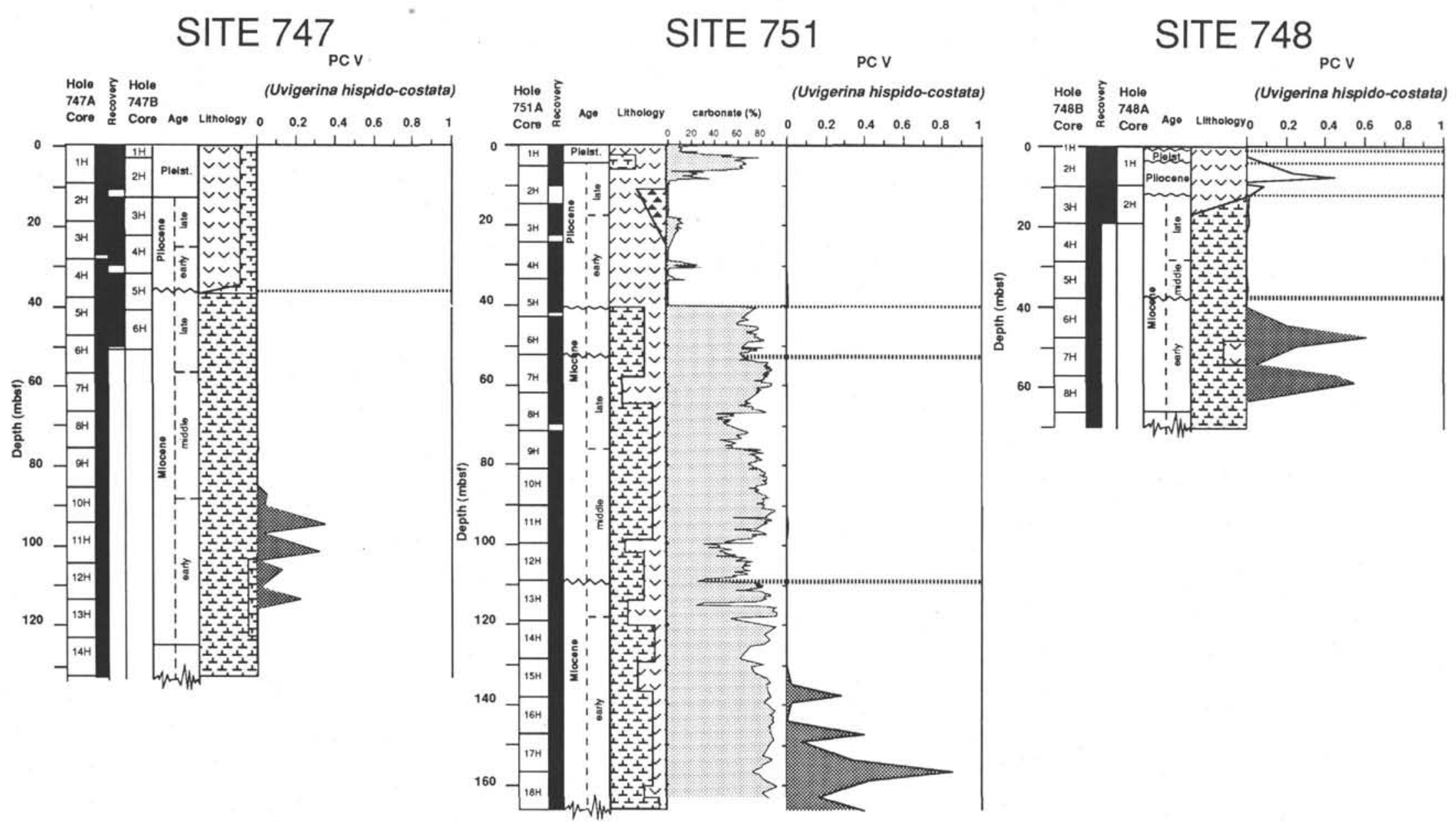

Figure 1. Squared principal component loadings of PC V plotted vs. sub-bottom depth ( $\mathrm{PC}$ value $\times 100$ gives percentage of total variance within reduced data set, which is explained in any particular sample by this particular PC). The high loadings of some Pliocene samples are probably a result of taxonomic mingling of different Uvigerina species and are interpreted to be not significant. 
748B it was found in six samples from 57.10 through 40.32 mbsf (120-748B-7H-CC through -6H-2, 72-76 cm) (Fig. 2).

The benthic foraminifer fauna is characterized by the dominance of $N$. umbonifer. Astrononion pusillum and Epistominella exigua are common but less abundant constituents. This assemblage differs from the older Uvigerina hispidocostata assemblage by the absence or very low number of uvigerinids. The $N$. umbonifer assemblage accounts for $35.14 \%$ of the total variance in the reduced data set.

At the lower/middle Miocene boundary (corresponding to $16.2 \mathrm{Ma}$ ), between 120.56 and 114.35 mbsf (4 samples from $120-751 \mathrm{~A}-14 \mathrm{H}-2,36-40 \mathrm{~cm}$, through $-13 \mathrm{H}-4,65-69 \mathrm{~cm})$, Gavelinopsis lobatulus reaches more than $10 \%$ of the benthic foraminifer assemblage, whereas below and above this $\approx 6-\mathrm{m}$ thick horizon this species is absent. Gavelinopsis lobatulus is also found, although in low numbers, centered on $77.81 \mathrm{mbsf}$ in Hole $747 \mathrm{~A}$ sediments.

\section{Astrononion pusillum Assemblage (PC III): Late Middle Miocene and Middle Late Miocene}

In Site 751 sediments, this assemblage was found in 14 samples from Sample $120-751 \mathrm{~A}-11 \mathrm{H}-2,72-76 \mathrm{~cm}$, through $-9 \mathrm{H}-\mathrm{CC}$ and from $120-751 \mathrm{~A}-8 \mathrm{H}-4,72-76 \mathrm{~cm}$, through $-5 \mathrm{H}-\mathrm{CC}$ (92.42-80.70 and 66.92-42.70 mbsf, respectively). In Hole $747 \mathrm{~A}$ it is represented by seven samples in Sample 120-747A$7 \mathrm{H}-2,72-76 \mathrm{~cm}$ ( $58.72 \mathrm{mbsf}$ ), and above an intercalation of a 10 -m-thick sequence with the $N$. umbonifer assemblage, again from Samples 120-747A-6H-2, 72-76 cm, through $-4 \mathrm{H}-2$, $72-76 \mathrm{~cm}$ (49.22-30.22 mbsf). At Site 751, the A. pusillum Assemblage is interrupted by an 11-m-thick sequence characterized by the $N$. umbonifer assemblage in lower upper Miocene sediments, between 66.92 and 77.92 mbsf (Fig. 3). The benthic foraminifer fauna is characterized by the dominance of Astrononion pusillum. It differs from the younger $E$. exigua assemblage by the presence of $A$. pusillum and the very low number of $E$. exigua and from the Nuttallides umbonifer assemblage by the absence of $N$. umbonifer. The A. pusillum assemblage accounts for $11.6 \%$ of the total variance in the reduced data set.

In the upper Miocene sequence of Hole 748B, this assemblage does not contribute significantly to the benthic foraminifer fauna; however, it should be mentioned that the relative abundance of Astrononion pusillum already was high in the very early Miocene of Hole $748 \mathrm{~B}$ as well as in Hole $747 \mathrm{~A}$. Analyses of Paleogene benthic foraminifer faunas of Sites 747 and 748 depicted that $A$. pusillum originated somewhere in the middle early Oligocene (Mackensen and Berggren, this volume). However, even though this species was common in Oligocene samples, it was found in a benthic foraminifer assemblage dominated by the Cibicidoides mundulus group and associated with $N$. umbonifer. This is in contrast to the Neogene $A$. pusillum assemblage as defined in this paper.

\section{Cibicidoides Assemblage (PCs VI and VII): Late Miocene through Late Pliocene}

Principal component analyses revealed two groups that are characterized by Cibicidoides mundulus (PC VI) and Cibicidoides spp. (VII). These groups are important only at Site 748, which has the shallowest present-day water depth (Fig. 4). There seems to be a succession from the $C$. mundulus group from 38.10 through $11.82 \mathrm{mbsf}$ to the younger Cibicidoides spp. group from 9.60 through 6.82 mbsf. However, for the sake of clarity, and because of the difficulties in taxonomic differentiation between different Cibicidoides species at this state of research, I grouped PCs VI and VII together. The ecological preferences of these different, but all epibenthic living, Cibicidoides species seem to be the same. Accessory species are Pullenia bulloides, Pyrgo murrhina, Oridorsalis umbonatus, Gyroidinoides soldanii, and in the older parts, $A$. pusillum.

In Hole 748B sediments, this assemblage was recognized in 14 samples from $120-748 \mathrm{~B}-5 \mathrm{H}-\mathrm{CC}$ through $-2 \mathrm{H}-5,72-76 \mathrm{~cm}$. The Cibicidoides assemblage accounts for $7.5 \%$ of the total variance of the reduced data set.

\section{Epistominella exigua Assemblage (PC IV): Latest Miocene through Late Pliocene}

Principal component analysis revealed an E. exigua-dominated fauna, which in the uppermost sections includes few $T$. angulosa and many of the common accessory constituents of the two younger assemblages. The downcore distribution of this fauna is poorly documented because of the extremely poor preservation of calcareous foraminifers in the lower Pliocene sections at all sites. There, the E. exigua assemblage is thought to be represented by its arenaceous remnants Martinotiella nodulosa, Eggerella bradyi, and Karreriella bradyi (see discussion that follows). In the sediments of Hole $751 \mathrm{~A}$ the benthic foraminifer fauna of 27 samples from Sample $120-751 \mathrm{~A}-5 \mathrm{H}-6,0-4 \mathrm{~cm}$, through $-2 \mathrm{H}-2,36-40 \mathrm{~cm}(40.70-$ $6.56 \mathrm{mbsf})$, are grouped into this assemblage. In Hole $747 \mathrm{~A}$ four samples from $120-747 \mathrm{~A}-3 \mathrm{H}-\mathrm{CC}$ through -2H-CC $(28.0$ $18.5 \mathrm{mbsf}$ ), are grouped together, and in Hole 748B this assemblage was not recognized (Fig. 5). The E. exigua assemblage accounts for $6.5 \%$ of the total variance in the reduced data set.

\section{Trifarina angulosa Assemblage (PC II): Early Pleistocene}

This assemblage is characterized by the dominance of $T$. angulos $a$ and by the absence of $B$. aculeata. Common accessory constituents include Pullenia bulloides, $P$. subcarinata, Melonis barleeanus, Eggerella bradyi, Ehrenbergina glabra, and Pyrgo murrhina. In Hole $751 \mathrm{~A}$ sediments, this fauna is represented by seven samples between 6.14 and $2.80 \mathrm{mbsf}$ (Samples 120-751A-2H-1, 144-148 cm, through -1H-2, 130$134 \mathrm{~cm}$ ); in Hole 747A by three samples between 14.22 and 9.00 mbsf (Samples 120-747A-2H-4, 72-76 cm, through -1H$\mathrm{CC}$ ); and in Hole 748B by four samples between 6.04 and 0.46 mbsf (Samples 120-748B-2H-4, 144-148 cm, through -2H-1, $36-40 \mathrm{~cm}$ ) (Fig. 6). The $T$. angulosa assemblage accounts for $14.6 \%$ of the total variance in the reduced data set.

\section{Bulimina aculeata Assemblage (PC VIII): Late Early Pleistocene through Holocene}

In Hole 751A sediments, this assemblage is represented by eight samples from 120-751A-1H-2, 82-86 cm, through $-1 \mathrm{H}-1$, $0-4 \mathrm{~cm}$ (2.32-0 mbsf); in Hole 747A by three samples from $120-747 \mathrm{~A}-1 \mathrm{H}-4,72-76 \mathrm{~cm}$, through $-1 \mathrm{H}-1,25-28 \mathrm{~cm}(5.22-$ $0.25 \mathrm{mbsf}$ ); and in Hole 748B by two samples (120-748B-2H-1, $0-4 \mathrm{~cm}$, and $-1 \mathrm{H}-\mathrm{CC}$ ) from $0.10 \mathrm{mbsf}$ (Fig. 7). The benthic foraminifer fauna is characterized by the presence of Bulimina aculeata and its co-occurrence with Trifarina angulosa. The common accessory species remain the same as in the $T$. angulosa assemblage. The Bulimina aculeata assemblage accounts for $3.2 \%$ of the total variance in the reduced data set.

\section{DISCUSSION}

\section{Biostratigraphy}

The biostratigraphic value of Neogene benthic foraminifer species is very limited because the most common species are long ranging and the shorter ranged species are rare. Most living calcareous deep-sea species evolved since the early Miocene, and $10 \%-20 \%$ of the total have origins before the Oligocene (Douglas and Woodruff, 1981, p. 1317). Depending 


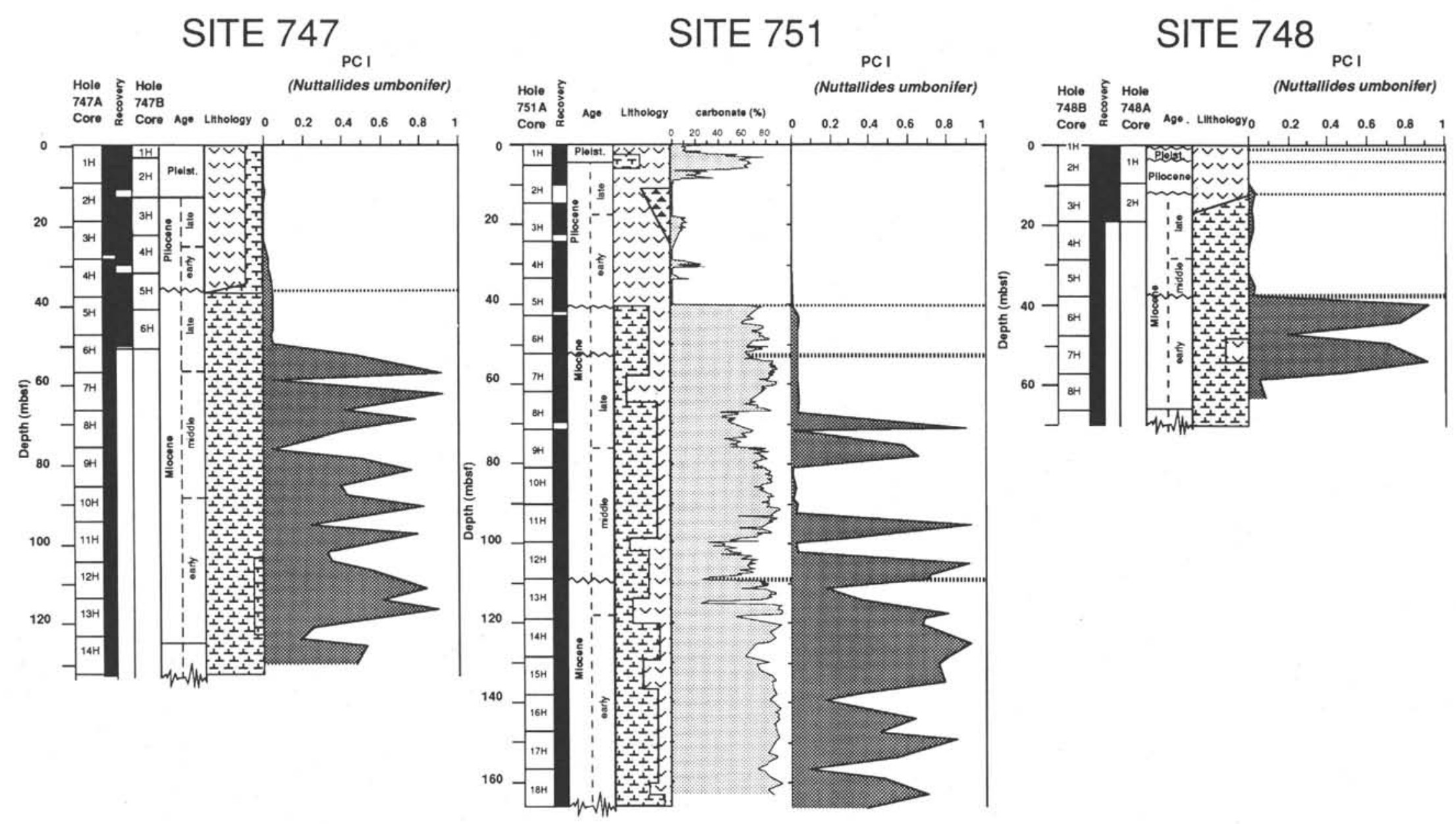

Figure 2. Squared principal component loadings of PC I plotted vs. sub-bottom depth (PC value $\times 100$ gives percentage of total variance within reduced data set, which is explained in any particular sample by this particular PC). 


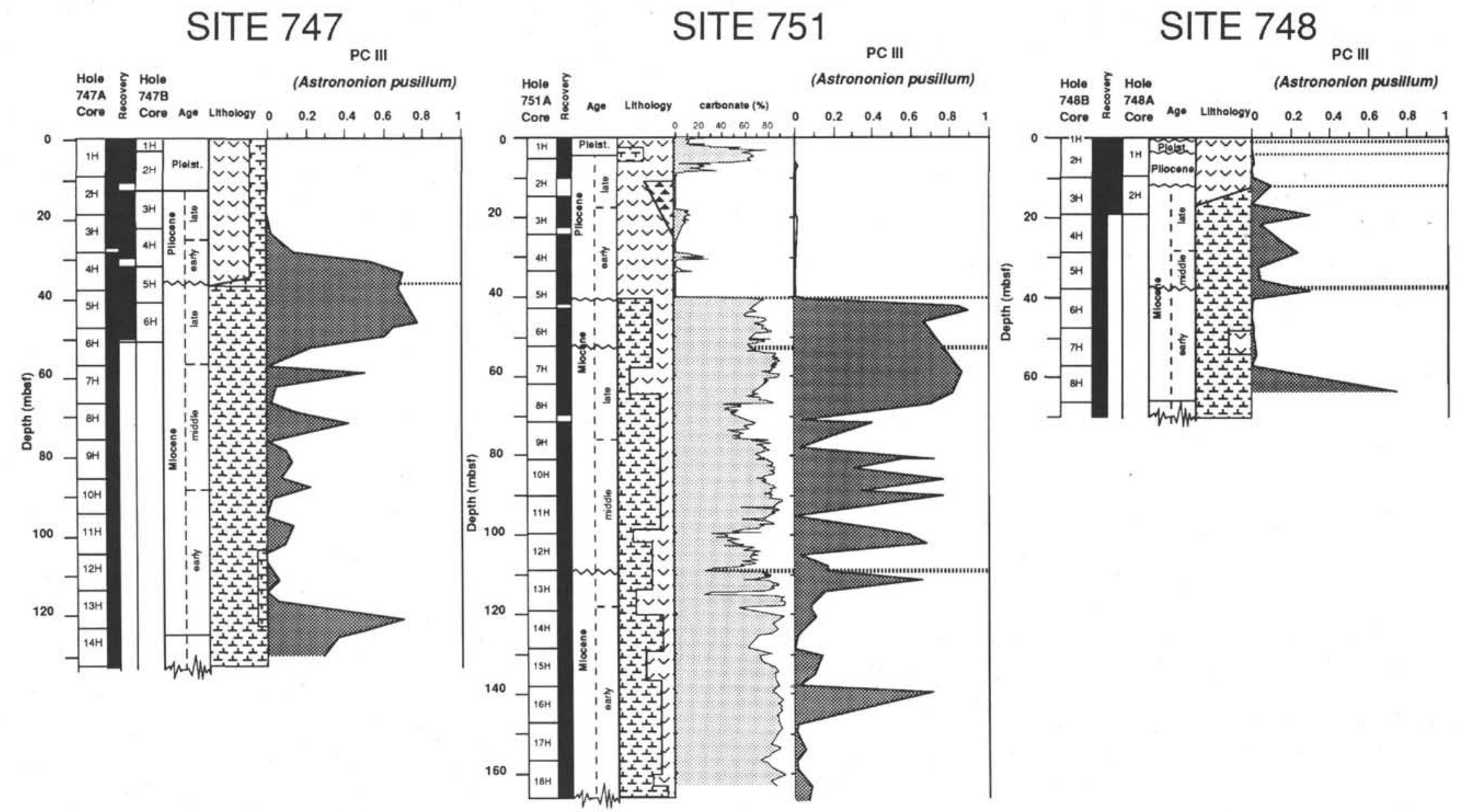

Figure 3. Squared principal component loadings of PC III plotted vs. sub-bottom depth (PC value $\times 100$ gives percentage of total variance within reduced data set, which is explained in any particular sample by this particular PC). 


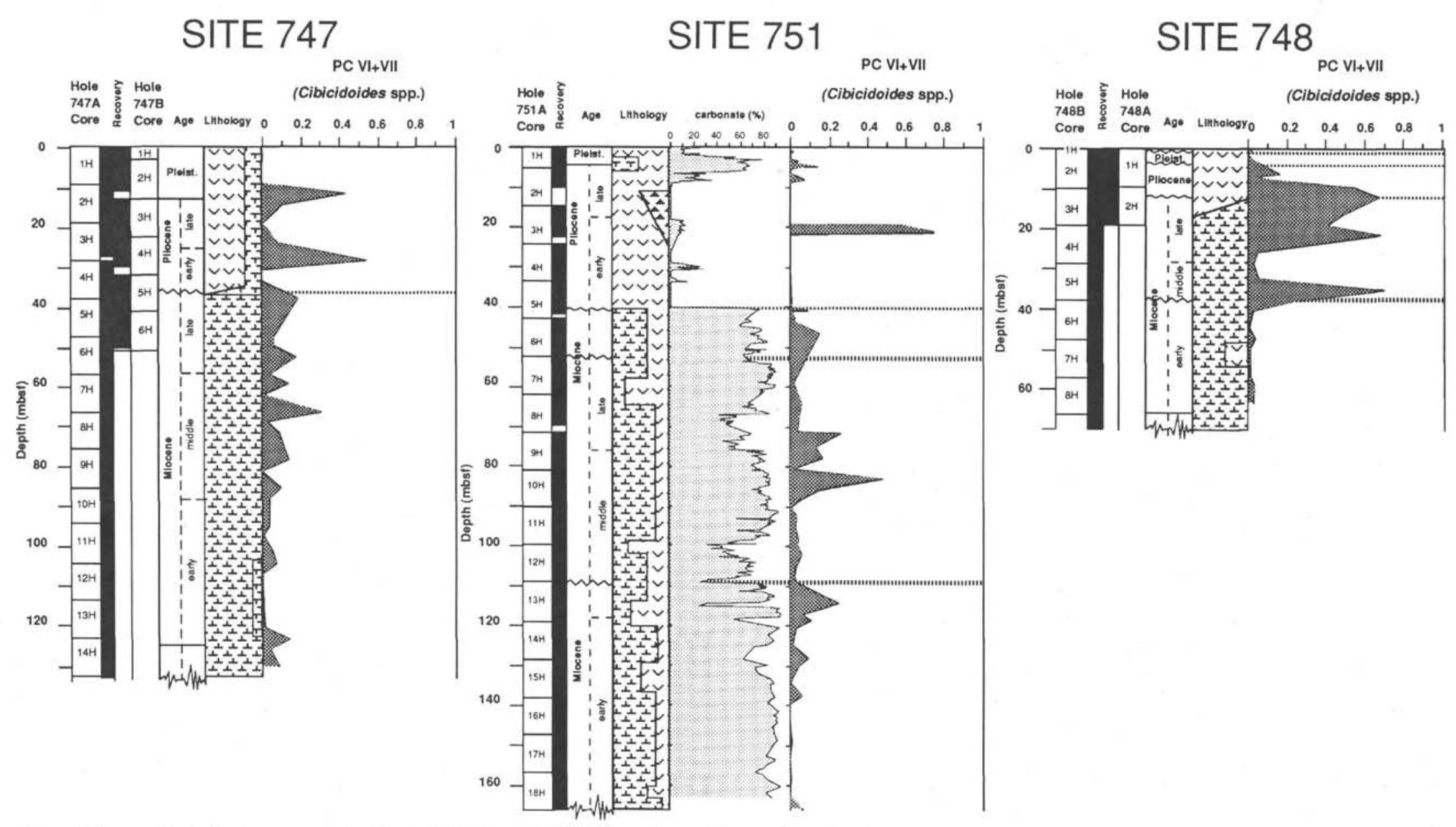

Figure 4. Squared principal component loadings of PC VI and PC VII plotted vs. sub-bottom depth (PC value $\times 100$ gives percentage of total variance within reduced data set, which is explained in any particular sample by these PCs). 
on the species concepts, other authors give even longer ranges for many species, Boltovskoy (1987) calculated that as much as $44.8 \%$ of the Quaternary species evolved before the Oligocene. First and last appearance dates of benthic foraminifer species are usually not coeval at different sites worldwide because of vertical and lateral migration (Tjalsma and Lohmann, 1983; Miller and Katz, 1987; van Morkhoven et al., 1986; Thomas and Vincent, 1987; Kurihara and Kennett, 1988).

All of the common species from the Neogene sediments of Sites 747,748 , and 751 are known to have stratigraphic ranges from at least the early Miocene to the Holocene. Therefore, the stratigraphic value of these data is discussed from the ecological point of view only.

\section{Paleoecology}

From studies on Holocene benthic foraminifer assemblages, it is known that the vertical and lateral distribution of benthic foraminifer species is governed by a complex set of environmental conditions (Lohmann, 1978; Schnitker, 1980; Douglas and Woodruff, 1981; Corliss, 1983; Lutze and Coulbourn, 1984; Mackensen et al., 1985, 1990; Corliss and Chen, 1988). Temporal changes in the environmental setting cause vertical and lateral migration of species. Although this fact complicates biostratigraphic interpretation, it does enable us to reconstruct paleoenvironmental conditions on the basis of benthic foraminifer faunal changes-as long as the recent analogies are sufficiently investigated and deciphered.

Because the reliability of paleoenvironmental interpretations of benthic foraminifer assemblages decreases with increasing age or depth, I will discuss the faunas investigated from the Holocene to the early Miocene.

\section{Quaternary and Pliocene}

The late Pleistocene Bulimina aculeata assemblage (PC VIII) is characterized by the well-known cosmopolitan Bulimina aculeata, which is reported to be correlated with high organic carbon (Olausson, 1960) and high mud content (Van der Zwaan, 1982). On the eastern Weddell Sea continental slope, the distribution of a live $B$. aculeata assemblage implies that this species prefers water temperatures warmer than $0^{\circ} \mathrm{C}$ and a fine substrate as well as low bottom current activities that do not hamper particulate organic matter (POM) fluxes (Mackensen et al., 1990). At the eastern Weddell Sea continental margin, this biocoenosis seems to prefer the high POM-flux zone that is associated with the water-mass boundary between the Weddell Deep Water (WDW) and the Antarctic Bottom Water (AABW).

At Sites 747, 748, and 751, the Trifarina angulosa assemblage (PC II) was found stratigraphically below the $B$. aculeata assemblage. Trifarina angulosa (also documented as $T$. earlandi, Angulogerina angulosa, A. carinata, and Uvigerina bassensis) today seems to be present all around Antarctica on the shelf, the shelf break, and the upper continental slope: it is found in surface sediments from the eastern Weddell Sea (Anderson, 1975; Mackensen et al., 1990), the Cosmonaut Sea (Uchio, 1960), the Adelie-George V continental slope (Milam and Anderson, 1981), the Ross Sea (Osterman and Kellogg, 1979), off King George Island ( $\mathrm{Li}$ and Zhang, 1986), the southern and eastern Falkland Plateau area (Herb, 1971; Mead, 1985), and the Kerguelen Plateau (Lindenberg and Auras, 1984, and this volume).

On the Norwegian continental margin and on the IcelandFaeroe Ridge, live benthic foraminifer assemblages dominated by $T$. angulosa are found strongly correlated to sandy substrates and high bottom current velocities, independent of such conservative water-mass characteristics as temperature and salinity (Mackensen et al., 1985; Mackensen, 1987). On the eastern Weddell Sea continental margin, this assemblage was also found to be associated with sandy sediments and a depositional regime in which sedimentation of finer grain sizes is hampered by a branch of the ACC (Mackensen et al., 1990), which is forced in this area toward the southwest as part of the Weddell Gyre System (Whitworth, 1988). In the eastern Weddell Sea (Mackensen et al., 1990), and below the South Atlantic Polar Frontal Zone (Mead and Kennett, 1987), T. angulosa-dominated faunas populate the slopes bathymetrically above a $B$. aculeata assemblage.

In summary, the ecological preferences of the $T$. angulosa and $B$. aculeata assemblages, as derived from investigations of Holocene polar environments, can be characterized as follows: the $T$. angulosa assemblage prefers shelf and upper slope conditions with sandy substrate and strong bottom currents, whereas the $B$. aculeata assemblage is found on upper to middle slope areas with calm sedimentation and high POM fluxes, usually just below a current system with moderate bottom current velocities.

Applying this to the fossil assemblage distribution found at the Kerguelen Plateau Sites 747, 748, and 751, the succession of $B$. aculeata on top of $T$. angulosa at all three sites suggests strong bottom currents from the upper late Pliocene. Then, in the upper early Pleistocene, at the two deeper and northern Sites 747 and 751 , periods of a weaker bottom current regime with calm sedimentation and high POM supply are intercalated. At the shallower Site 748 , the bottom current activities seem to have persisted longer up into the late Pleistocene, although the incomplete Pleistocene record makes this conclusion questionable.

Correlation with the $\delta^{18} \mathrm{O}$ record at Site 751 (Mackensen et al., this volume) indicates that during colder periods ("glacials") $T$. angulosa dominated and the bottom currents intensified, whereas less intense currents and sedimentation of particulate organic matter with $B$. aculeata-dominated faunas occurred during warmer ("interglacial") periods. Considering no significant changes in paleodepth, two principal explanations or a combination of these are possible: (1) the ACC was stronger during the late Pliocene and Pleistocene cold periods and/or (2) the sea level dropped significantly during those times, causing a deepening of the winnowing force of the ACC. Both of the explanations make paleoceanographic sense. During periods of global cooling, the climatic gradients between the equatorial and polar regions increase, which causes an increasing westward wind drift. This, in turn, increases circum-antarctic surface current velocities including the ACC. It is also well known that the sea level was lowered by about $150 \mathrm{~m}$ worldwide during glacials. This and a growing continental ice cap may have caused the Antarctic ice shelves, such as Ronne and Filchner ice shelves in the Atlantic sector of the Southern Ocean, Amery ice shelf in the Indian Ocean sector, and Ross ice shelf in the Pacific ocean sector, to protrude their grounding line to the continental shelf break. Then, as a result of a different mode of bottom water formation, bottom currents may have changed depth.

The uppermost Miocene through the middle upper Pliocene of Hole 751A and the late Pliocene of Hole 747A is dominated by the Epistominella exigua assemblage (PC IV), whereas in Hole 748B the upper Miocene is characterized by an assemblage dominated by Cibicidoides. (The lower Pliocene was not properly sampled because of the condensed sequences.) Taking the absolute number of benthic foraminifers per volumeunit sample (Fig. 8) and the number of species per sample (Fig.9) as indicators for severe carbonate dissolution, low numbers of specimens and species coincide, of course, with extremely low carbonate contents (see the high-resolution 


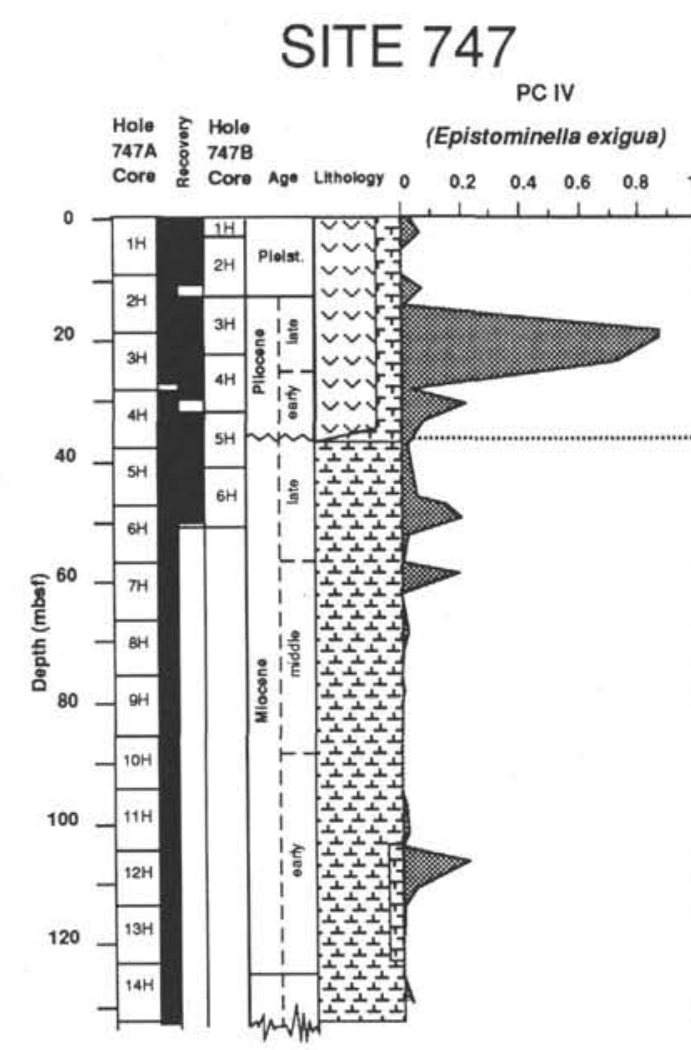

SITE 751

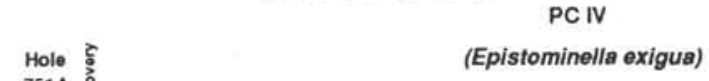

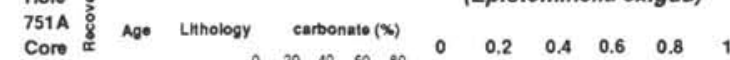

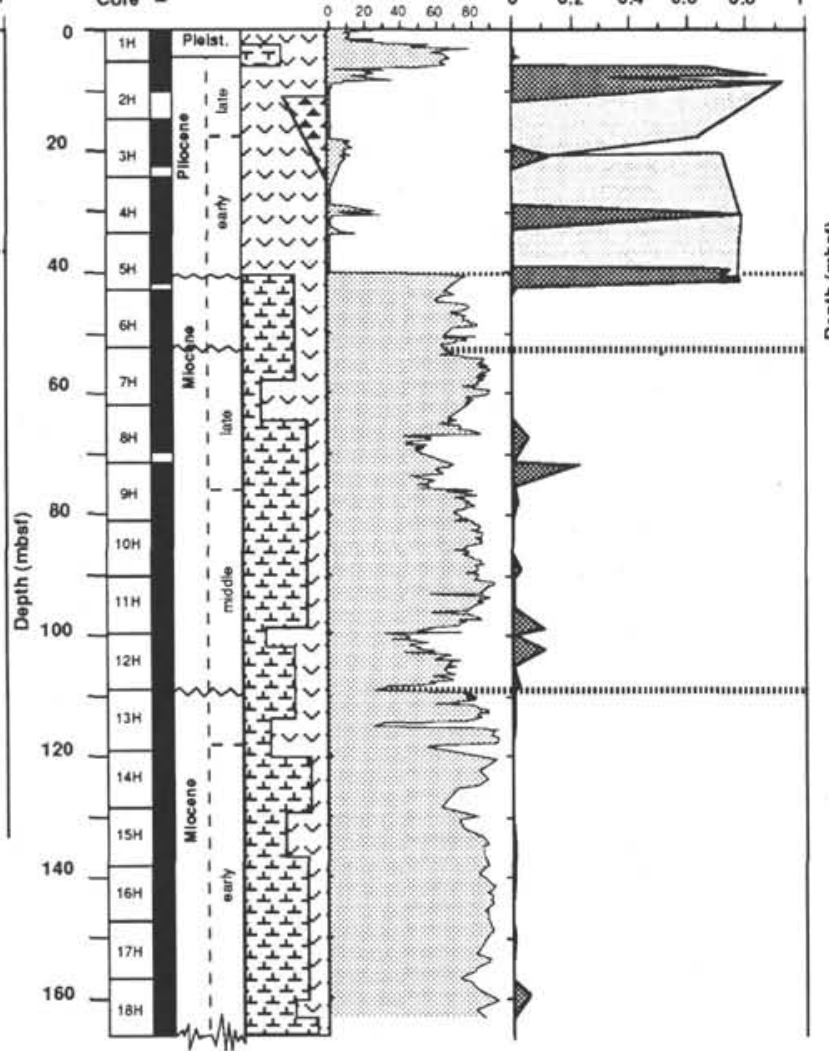

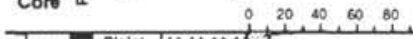

SITE 748

PCIV $\begin{array}{lllllll}\text { Core } & \text { \& Core Age Lthology } 0 & 0.2 & 0.4 & 0.6 & 0.8\end{array}$ \begin{tabular}{lllll}
\hline & 0.4 & 0.6 & 0.8
\end{tabular}

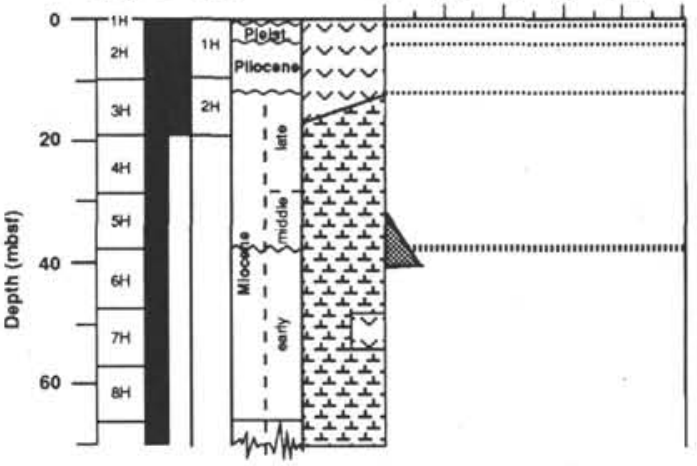

Figure 5. Squared principal component loadings of PC IV plotted vs. sub-bottom depth (PC value $\times 100$ gives percentage of total variance within reduced data set, which is explained in any particular sample by this particular PC). The light stippled area indicates samples that were not included in the PC-analysis, because of their low numbers of almost exclusively arenaceous benthic foraminifers. These samples are interpreted to represent the dissolution residue of PC IV (relict fauna of the $E$. exigua assemblage). 


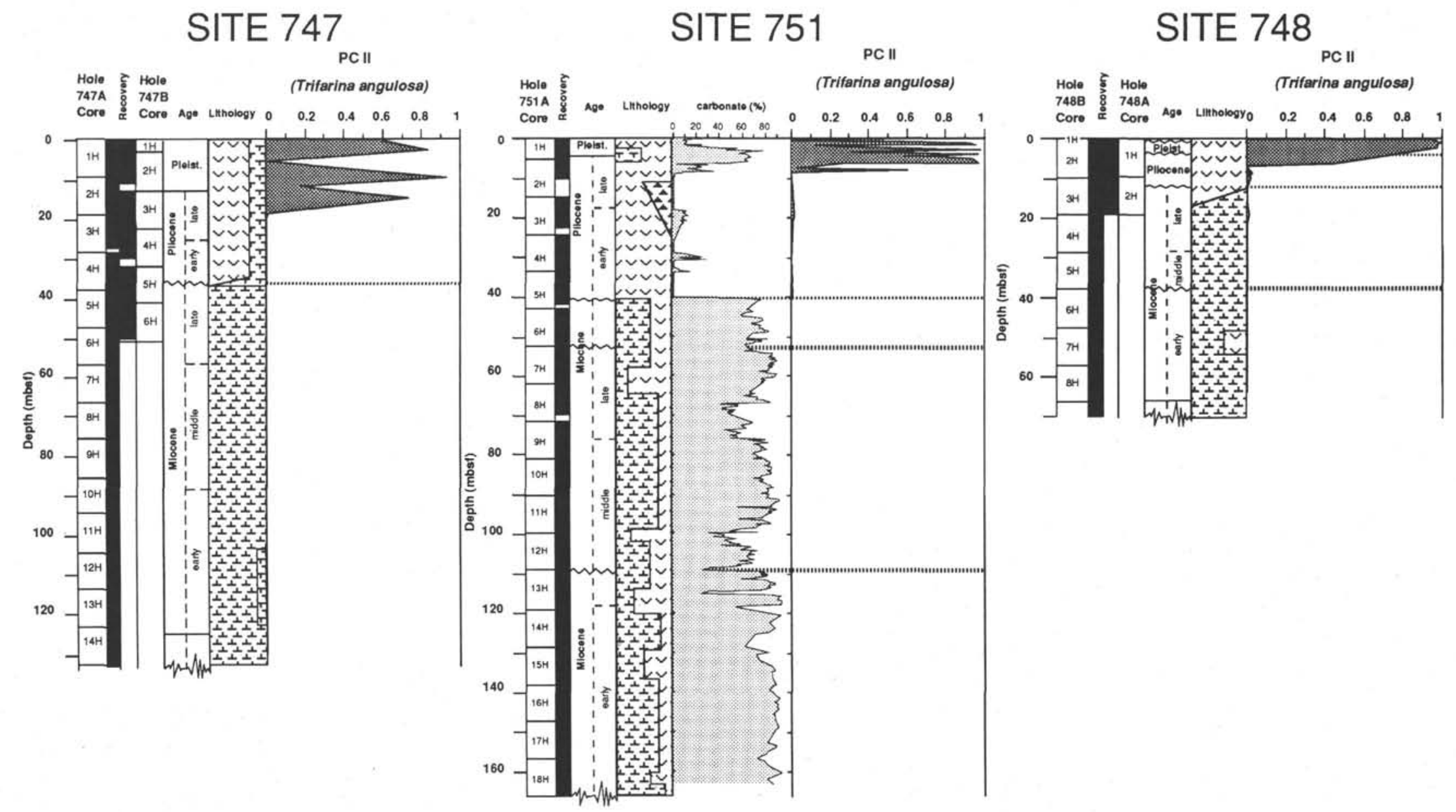

Figure 6. Squared principal component loadings of PC II plotted vs. sub-bottom depth (PC value $\times 100$ gives percentage of total variance within reduced data set, which is explained in any particular sample by this particular PC). 


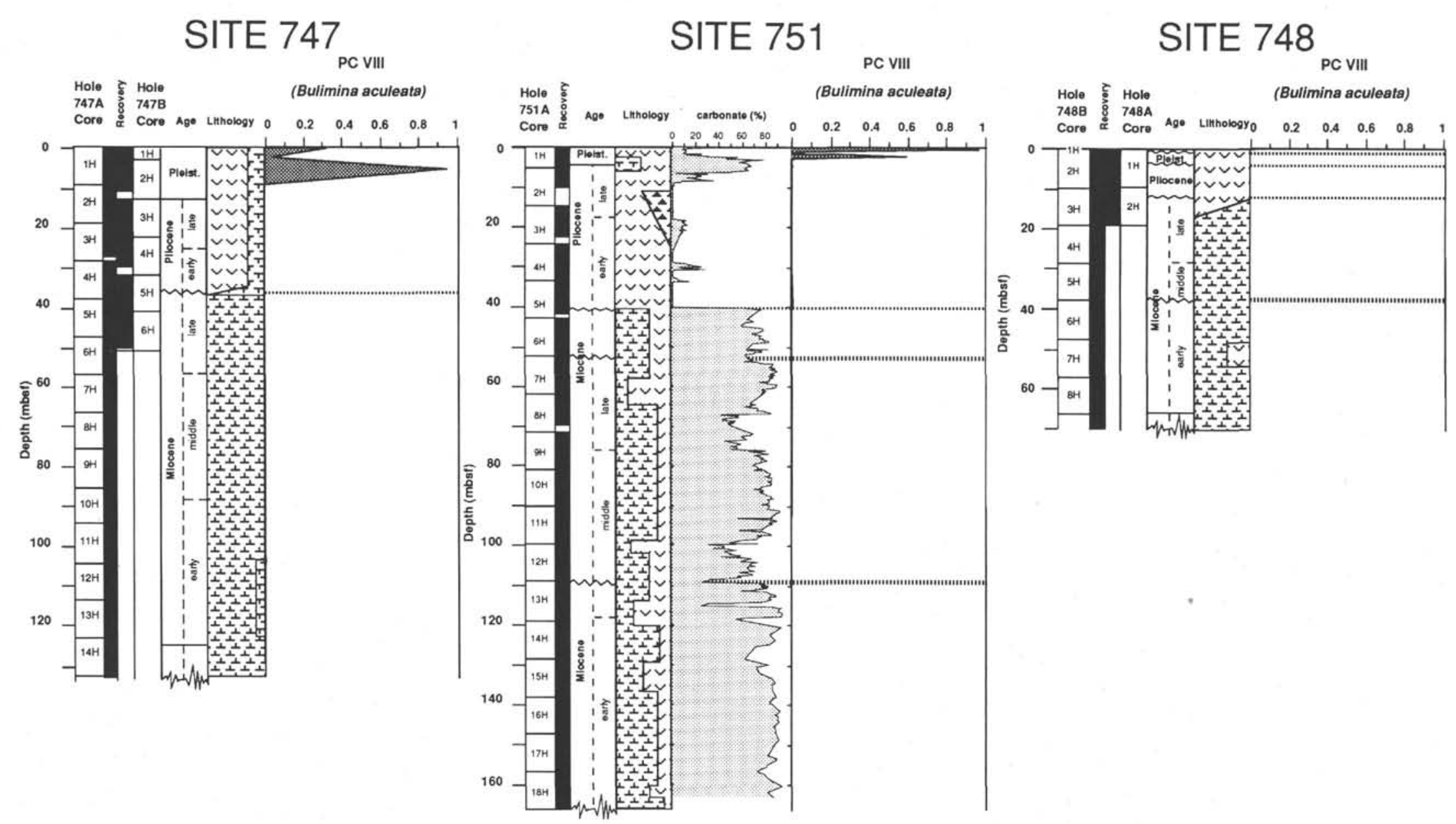

Figure 7. Squared principal component loadings of PC VIII plotted vs. sub-bottom depth (PC value $\times 100$ gives percentage of total variance within reduced data set, which is explained in any particular sample by this particular PC). 
carbonate record of Hole 751A in Mackensen et al., this volume). In addition, they indicate that in the early and early late Pliocene severe carbonate dissolution took place only in the two southern Holes $751 \mathrm{~A}$ and $748 \mathrm{~B}$. No reduction in species and specimen number was seen in Pliocene sediments at northern Site 747.

Because the carbonate-free and foraminifer-barren sections of Hole 751A are over- and underlain by the E. exigua assemblage, I assume that this assemblage was living there but not fossilized. From investigations of Holocene deep-sea samples, it has been demonstrated that $E$. exigua is an epibenthic living species (Mackensen et al., 1985; Mackensen, 1987; Corliss and Chen, 1988) that tends to live within the flocculent layer and feeds on phytodetritus (Gooday, 1988). Consequently, a scenario is proposed with seasonally very high biosiliceous productivity, which would serve as an ample food source for the $E$. exigua assemblage but would also cause almost instantaneous dissolution of the empty tests after reproduction of the animals and loss of their protective outer organic linings (Mackensen et al., 1990). In the more calcareous sediments of Hole 747A, the coeval dominance of the $E$. exigua assemblage during the early late Pliocene may indicate high productivity as well, but with a higher amount of calcareous algae and of the planktonic foraminifer Neogloboquadrina pachyderma, which prevented calcite undersaturation of bottom and pore waters. In a strict analogy to today's oceanography, this would mean that Site 747 was situated north of the Polar Front and south of the Subantarctic Front, whereas Sites 751 and 748 would have been within the Antarctic Zone (i.e., south of the Polar Front).

At Site 748, which is $400 \mathrm{~m}$ shallower, the Pliocene dissolution event is indicated by an abrupt drop in the number of benthic foraminifer specimens and in species number (Figs. 8 and 9). Below this, a Cibicidoides-dominated fauna was found. Most of the species of the Cibicidoides group (e.g., $C$. wuellerstorfi) are attached, living epibenthic species (Lutze and Thiel, 1988) that prefer areas of high primary productivity and a substrate with rough micro-relief, which implies some bottom current activities hampering the buildup of a clayey veneer or flocculent layer (Mackensen et al., 1985).

In summary, on the Southern Kerguelen Plateau, distinct intervals within the early and early late Pliocene with severe carbonate dissolution are recognized only south of Site 747 and at Sites 751 and 748. These dissolution events are also reported from the Maud Rise (Barker, Kennett, et al., 1988) and from Southern Kerguelen Sites 738 and 744 (Ehrmann, 1991). I have suggested that high primary productivity (diatoms) south of the Polar Front, which should have been situated further south compared with its present-day position, shoaled the local CCD below the positions of Sites 751 and 748. In addition, the different epibenthic foraminifer assemblages at Sites 751 and 748 have also indicated that the 400 -m-shallower Site 748 was influenced by gentle winnowing of the ACC during late Miocene-early Pliocene times. The lack of a severe carbonate dissolution in Pliocene sediments of Site 747 indicates a position north of the Polar Front but south of the Subantarctic Front.

\section{Miocene}

The Astrononion pusillum Assemblage (PC III) dominates the benthic foraminifer faunas in Sites 747 and 751 from upper Miocene through middle lower Pliocene and uppermost Miocene sediments, respectively. Below these sections the sediments, deposited during latest middle and early late Miocene time, in both holes contain a benthic foraminifer fauna that is dominated by $N$. umbonifer (PC I). In Hole $751 \mathrm{~A}$ the latter sequence coincides with a drop in carbonate content of about
$20 \%$ (Figs. 2 and 3 ) and in Hole 747A with a significant drop of the benthic foraminifer number (Fig. 8). Below these sediments, the $A$. pusillum assemblage again dominates the benthic foraminifer fauna, but only for a short interval in the upper middle Miocene. However, from the late early through the late middle Miocene, the fauna of the more northern and deeper Sites 747 and 751 was characterized by $N$. umbonifer (Fig. 10). In Hole 748B the $N$. umbonifer assemblage, after a hiatus in the middle Miocene, had shifted to a Cibicidoidesdominated fauna.

Astrononion echolsi Kennett, a junior synonym or a very close relative of A. pusillum Hornibrook, is found in Holocene sediments in significant abundances in the southwest Indian Ocean between 1600 and $3800 \mathrm{~m}$ water depth (Corliss, 1983). There it is a major constituent of a benthic foraminifer assemblage characterized by $C$. wuellerstorfi and $G$. subglobosa. Corliss (1983) found this fauna associated with North Atlantic Deep Water (NADW) in contrast to the N. umbonifer-dominated fauna that he found to be associated with AABW. However, on the eastern Weddell Sea continental margin, a Holocene $N$. umbonifer-dominated fauna is associated with $\mathrm{AABW}$ only in areas and water depths between the calcite lysocline and the CCD (Mackensen et al., 1990). This new data set corroborates investigations of Bremer and Lohmann (1982) and Corliss (1983), who proposed that N. umbonifer is especially adapted to live within a carbonateundersaturated environment. In addition, it clearly excludes former investigations, suggesting that empty $N$. umbonifer tests were more resistant to dissolution than other benthic foraminifer tests and, therefore, after the death of the animal, became enriched in sediments that were exposed to carbonate-aggressive water masses.

Summarizing the benthic foraminifer record in Holes 747 A, $748 \mathrm{~B}$, and $751 \mathrm{~A}$ from middle lower through upper Miocene sediments, I assume a carbonate-undersaturated, bottomwater environment during the middle and late early Miocene up to the middle middle Miocene (Fig. 10, PC I). Then, significantly after the middle Miocene cooling event $(\approx 110$ mbsf in Hole 751A), a water mass similar to aged NADW (i.e., nutrient-enriched, oxygen-poor, and low $\delta^{13} \mathrm{C}$-values; Mackensen et al., this volume) bathed the deeper Sites 747 and 751 (Fig. 10, PC III). After a short interruption at the middle to late Miocene boundary, when the carbonate-aggressive environment, indicated by the $N$. umbonifer assemblage (PC I) was reestablished, the NADW-like water-mass conditions, indicated by the $A$. pusillum assemblage (PC III, i.e. $A$. pusillum without $N$. umbonifer) seem to have been stable from about 11 Ma until late early Pliocene times at Site 747 and until late late Miocene times at Site 751 (Fig. 10). According to Woodruff and Savin (1989), there was no (or only a weak) formation of NADW before $11 \mathrm{Ma}$. The dominance of the $A$. pusillum assemblage, which may indicate a water mass similar to NADW, seems to agree with this. Because presently almost half of the CDW, which today is supposed to bathe the deeper sites below about $1500 \mathrm{~m}$ water depth, is constituted of Weddell Sea water and only $25 \%$ is contributed from the North Atlantic water (Emery and Meincke, 1986), the paleoceanographic development of the area under study is closely linked to changing conditions within the Weddell Sea.

Two principal scenarios are possible to explain carbonateundersaturated bottom water at around $1600 \mathrm{~m}$ water depth on the Southern Kerguelen Plateau through early and middle Miocene time:

1. the water mass itself is-similar to AABW (i.e., newly formed under and/or directly in front of ice shelves) - cold and oxygen-rich; or 


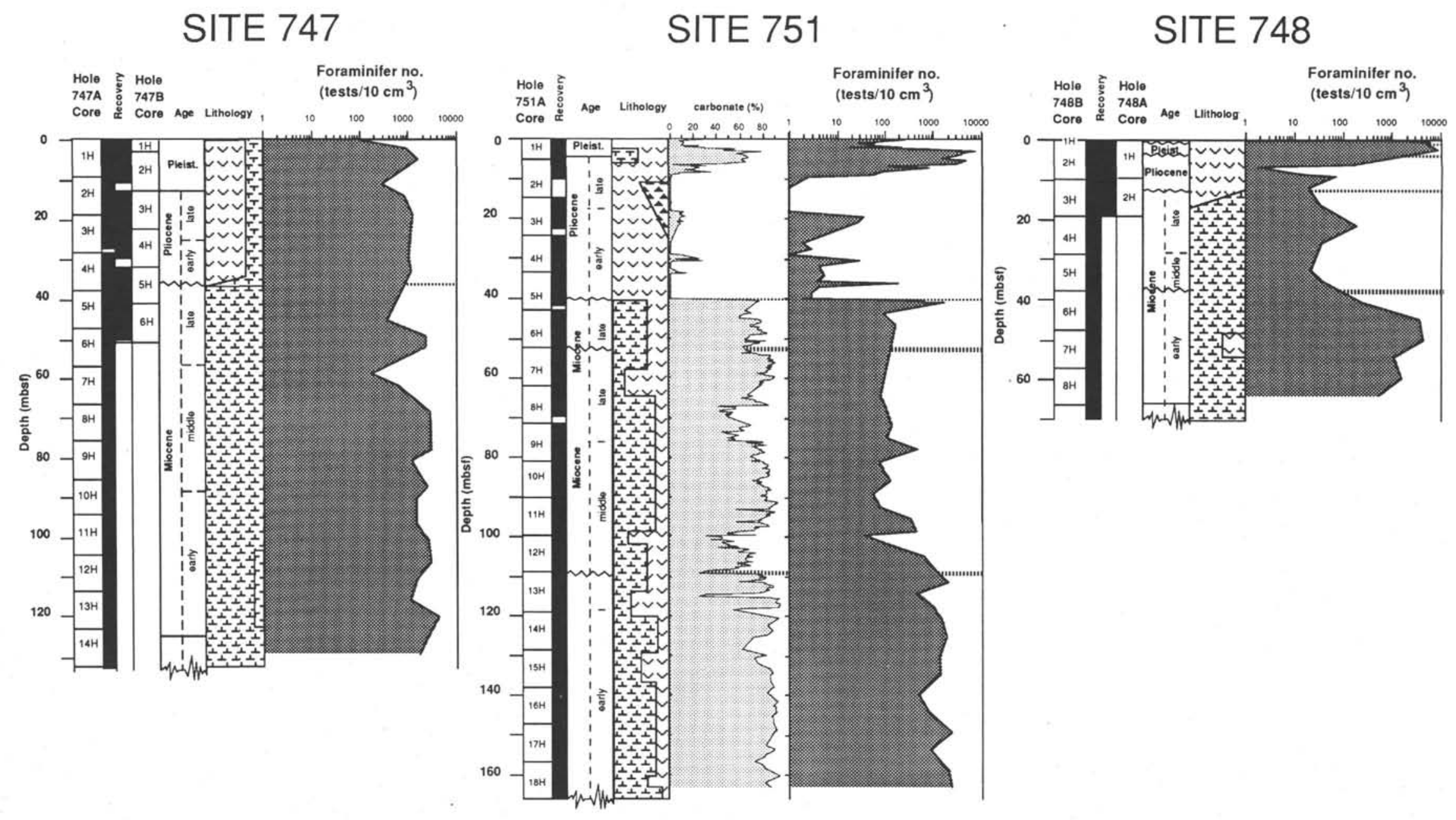

Figure 8. Number of benthic foraminifer (tests per $10 \mathrm{~cm}^{3}$ ) counted in each sample (without core-catcher counts) plotted vs. sub-bottom depth. 


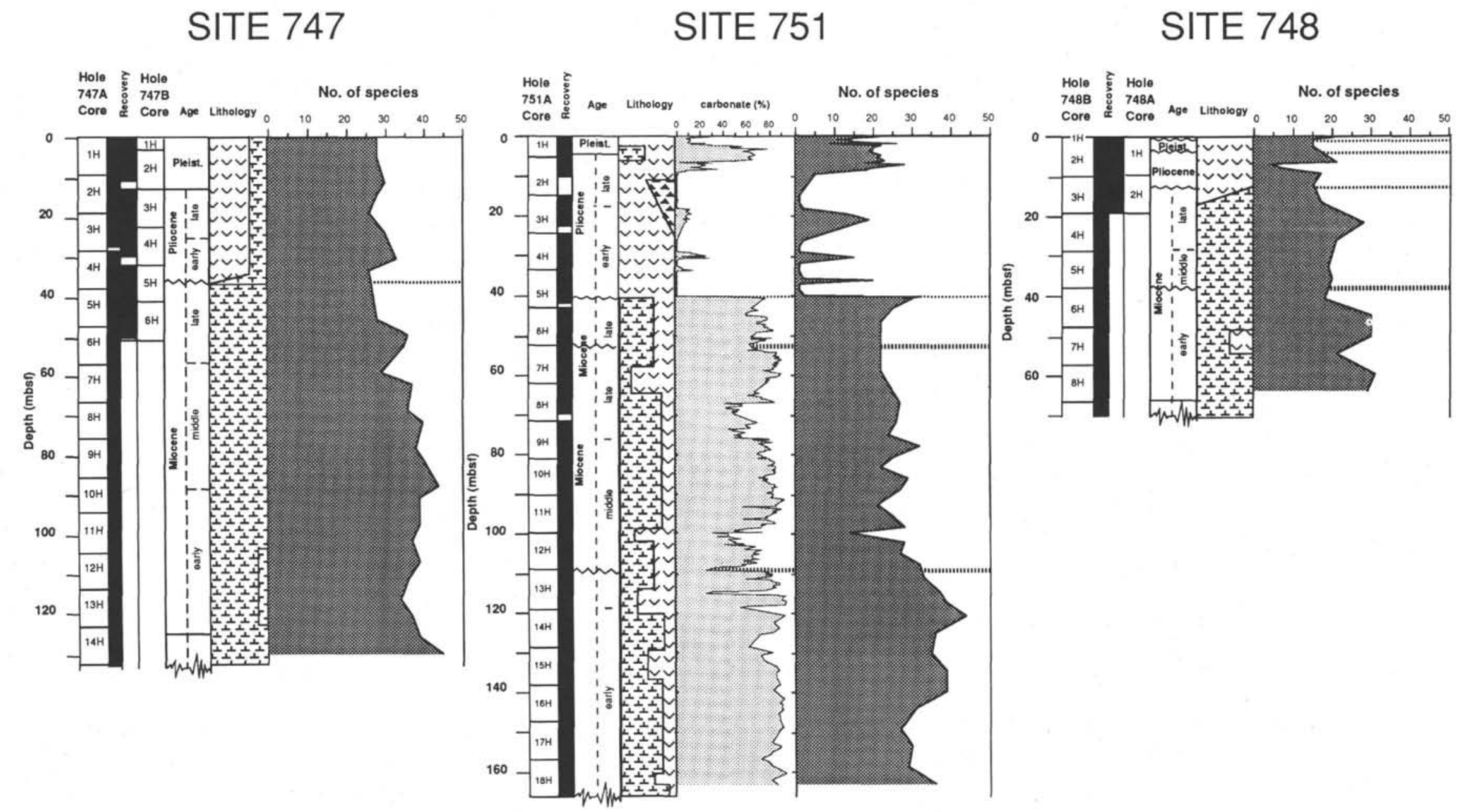



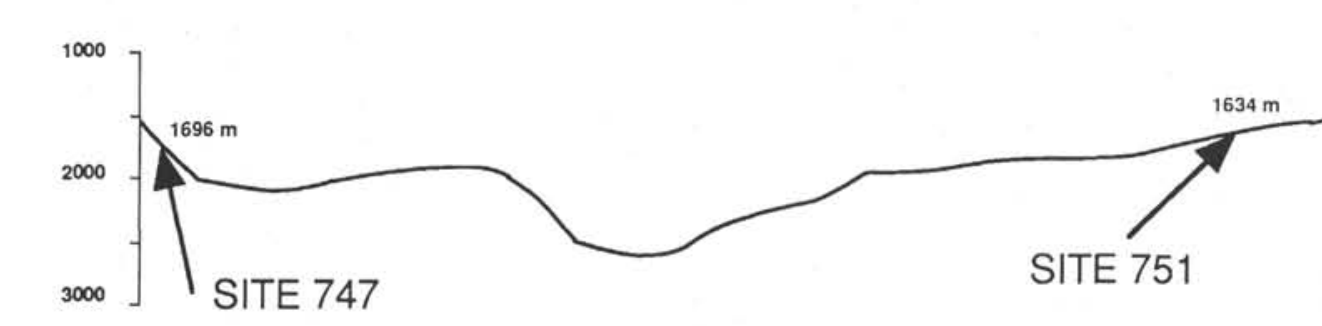

$\mathrm{S}$
离
旁
高

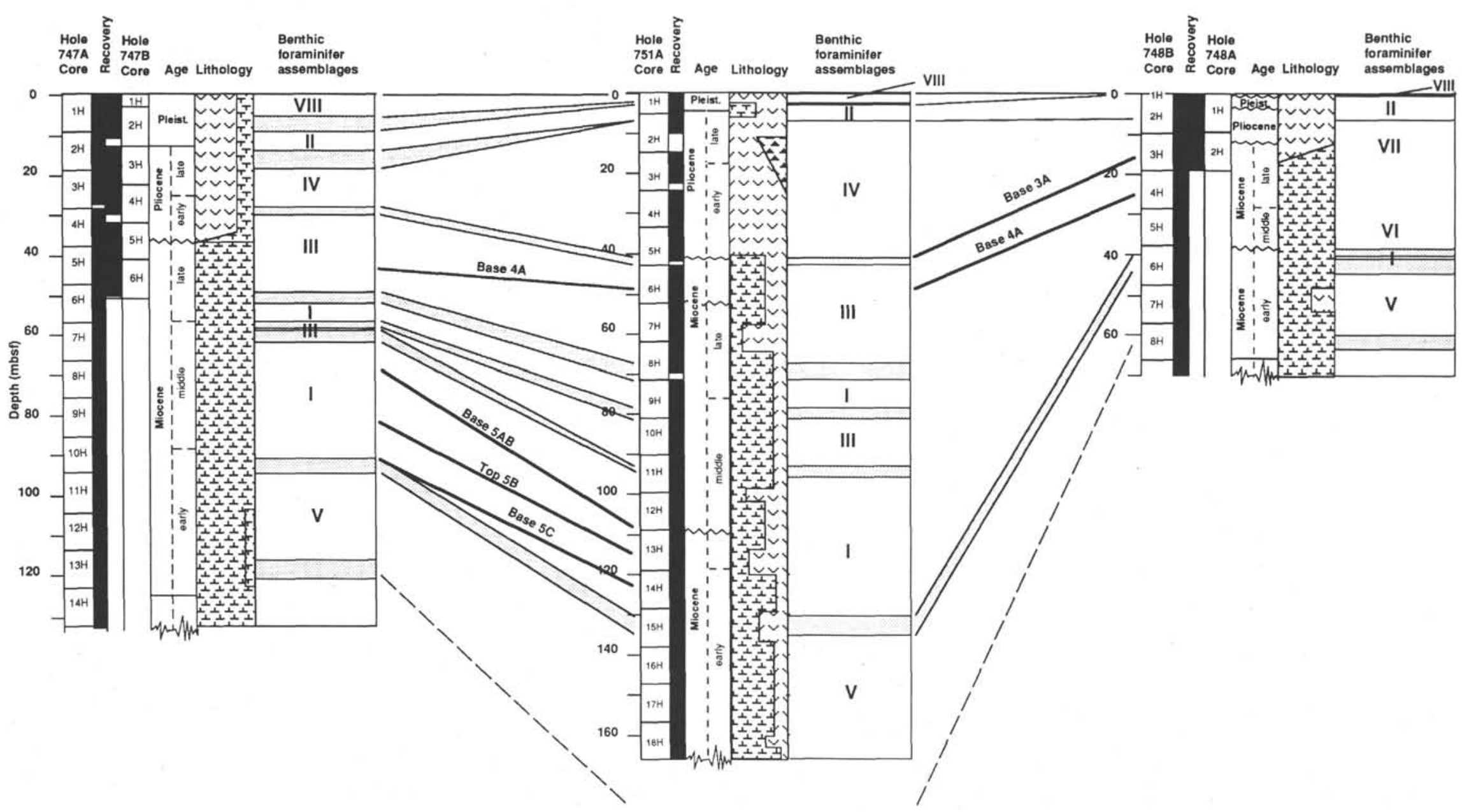

Figure 10. Comparison of sites investigated. The relative position of the sites according to present water depth (m below sea level [mbsl] after Schlich et al. [1987]). Below this, the correlation of benthic foraminifer boundaries between holes is given. The dense stippled pattern between lines gives an uncertainty interval of assemblage boundaries caused by the sampling density. Bold lines give bases and tops of magnetic anomaly correlatives for precise time correlation between Sites (Schlich, Wise, et al., 1989; see discussion in "Methods" section, "Stratigraphy and Paleodepth"). Benthic foraminifer assemblage boundaries may be diachronous because of vertical and lateral migration of assemblages triggered by changing environmental conditions at different places in different water depths at different times. 
2. a very high primary productivity in the surface waters causes high fluxes of organic material to the seafloor, where its decomposition and decay increases the $\mathrm{CO}_{2}$ content and therefore the calcite dissolution.

Hypothesis (1) is corroborated by the sedimentary record obtained by drilling during Leg 119 in Prydz Bay. The data suggest full-scale development of the East Antarctic Ice Sheet (i.e., the grounding line reached the paleoshelf break) for much of Oligocene through middle Miocene time with a retreat of the ice sheet in the late Miocene (Hambrey et al., 1991). It seems reasonable that beneath and in front of the ice shelf in Prydz Bay, saline and very cold water, which was highly corrosive relative to carbonate, was produced and consequently influenced the benthic foraminifer faunal composition on the nearby Southern Kerguelen Plateau. However, late Oligocene benthic foraminifer faunas from Sites 747 and 748 do have a strong $N$. umbonifer component, but they are dominated by the co-occurrence of Cibicidoides mundulus and $A$. pusillum (Mackensen and Berggren, this volume). This may indicate a less intense bottom water production during those times compared with the late early and middle Miocene.

Finally, a benthic foraminifer assemblage that is characterized by Uvigerina hispidocostata (PC V) is found in the lower Miocene sections of all the sites investigated. There has been much discussion whether the genus Uvigerina is especially adapted to high organic carbon flux rates and consequently might be a useful paleoproductivity indicator (Streeter, 1972), or whether, as a shallow infaunal species (Zahn et al., 1986), it prefers low-oxygen pore-water environments (Miller and Lohmann, 1982). However, because the pore-water oxygen content usually is low, if organic carbon fluxes are sufficiently high, the abundant presence of Uvigerina may indicate highly productive areas (Lutze and Coulbourn, 1984; Woodruff, 1985). Corliss and Chen (1988) grouped the benthic foraminifer species into epifaunal, shallow infaunal, and deep infaunal, based on shape analysis of data from the Norwegian continental margin (Mackensen et al., 1985), and associated the dominance of infaunal species with high organic carbon fluxes. Thomas (1990) followed this attempt and calculated the percentage of infaunal species from the Maud Rise and deduced that, if the infauna was dominant, either high primary productivity or poorly ventilated bottom-waters or a combination of both existed.

On the Southern Kerguelen Plateau, high productivity may have favored the occurrence of the $U$. hispidocostata assemblage in the early Miocene before the final deep opening of the Drake Passage and the dramatic cooling in the early middle Miocene. This is corroborated by the large differences between $\delta^{13} \mathrm{C}$ values of planktonic foraminifer and $\delta 13 \mathrm{C}$ values of Cibicidoides spp. at Site 751, which coincide to a certain extent with the presence of the Uvigerina fauna (Mackensen et al., this volume).

\section{CONCLUSIONS}

Benthic foraminifer assemblages from upper lower Miocene through Holocene sediments from Kerguelen Plateau Sites 747, 748 , and 751 are very similar to Holocene faunas, which today reside on the eastern Weddell Sea continental margin and in the bathyal and abyssal southwest Indian Ocean. Only a lower Miocene Uvigerina-characterized fauna has no Holocene analogue in southern high-latitude sediments.

There is no indication of a major benthic faunal turnover around 14-15 Ma. On the contrary, the data presented here indicate that Miocene bottom-water circulation did not change until late middle Miocene time. The probably most important benthic faunal change in the Miocene took place in the early late Miocene, when the Nuttallides umbonifer-dominated assemblage ultimately disappeared. This might indicate the retreat of carbonate-corrosive, newly formed bottom-water masses from the Kerguelen Plateau into deeper abyssal regions, and the occupation of the shallow bathyal regions by an aged NADW-like water mass.

From the latest Miocene at the southern Site 751, and from the middle early Pliocene at the more northern Site 747, a calcareous relict fauna, partly dominated by arenaceous foraminifers, otherwise characterized by Epistominella exigua, indicates the position of these sites below highly productive surface-water masses associated with the Antarctic polar frontal zone.

From the late late Pliocene through the middle Pleistocene, strong bottom currents at water depths between 1200 and 1700 mbsf are indicated by the dominance of the Trifarina angulosa assemblage.

During the late Pleistocene calm sedimentation at these water depths and high particulate organic matter supply is indicated by the Bulimina aculeata assemblage. There is evidence that a more detailed study of latest Pliocene and Pleistocene benthic foraminifer faunas at higher resolution will show a cyclic alternation of benthic foraminifer assemblages characterized by $T$. angulosa and Bulimina aculeata, respectively. Stable oxygen isotope analysis suggests that these cycles seem to be correlated to the worldwide climatic cycles in such a way that $T$. angulosa, indicative for vigorous bottom current activities, dominates during cold periods (Mackensen et al., this volume).

\section{ACKNOWLEDGMENTS}

I thank the master and crew of the JOIDES Resolution and the ODP technical staff for their work and assistance on-board ship. I am grateful to H. Grobe and W. U. Ehrmann for help, discussions, and thorough reviewing of an early draft of this manuscript. I also thank M. Heyn and A. Wolf for technical assistance. Critical reviews and valuable remarks of J. W. Murray, E. Thomas, and F. Woodruff are gratefully acknowledged. Financial support was given by the Deutsche Forschungsgemeinschaft. This is Alfred Wegener Institute Contribution No. 311 .

\section{REFERENCES}

Anderson, J. B., 1975. Ecology and distribution of foraminifera in the Weddell Sea of Antarctica. Micropaleontology, 21:69-96.

Barker, P. F., Kennett, J. P., and Leg 113 Shipboard Scientific Party, 1988. Weddell Sea palaeoceanography: preliminary results of ODP Leg 113. Palaeogeogr., Palaeoclimatol., Palaeoecol., 67:75-102.

Barnola, J. M., Raynaud, D., Korotkevich, Y. S., and Lorius, C., 1987. Vostok ice core provides 160,000 -year record of atmospheric $\mathrm{CO}_{2}$. Nature, 329:408-414.

Boltovskoy, E., 1987. Tertiary benthic foraminifera in bathyal deposits of the Quaternary world ocean. J. Foraminiferal Res., 17:279285.

Bremer, M. L., and Lohmann, G. P., 1982. Evidence for primary control of the distribution of certain Atlantic Ocean benthonic foraminifera by degree of carbonate saturation. Deep-Sea Res. Part A, 29:987-988.

Broecker, W. S., and Peng, T.-H., 1986. Global carbon cycle: 1985. Radiocarbon, 28:309-327.

Broecker, W. S., Takahashi, T., and Takahashi, T., 1985. Sources and flow patterns of deep-ocean waters as deduced from potential temperature, salinity, and initial phosphate concentration. J. Geophys. Res., 90:6925-6939.

Corliss, B. H., 1979. Recent deep-sea benthonic foraminifer distributions in the southeast Indian Ocean: inferred bottom-water routes and ecological implications. Mar. Geol., 31:115-138.

1983. Distribution of Holocene deep-sea benthonic foraminifera in the southwest Indian Ocean. Deep-Sea Res. Part A, 30:95-117. 
Corliss, B. H., and Chen, C., 1988. Morphotype patterns of Norwegian Sea deep-sea benthic foraminifera and ecological implications. Geology, 16:716-719.

Deacon, G.E.R., 1983. Kerguelen, Antarctic and Subantarctic. DeepSea Res., Part A, 30:77-81.

Douglas, R. G., and Woodruff, F., 1981. Deep-sea benthic foraminifera. In Emiliani, C. (Ed.), The Sea (Vol. 7): New York (WileyInterscience), 1233-1327.

Earland, A., 1933. Foraminifera, Pt. 2. South Georgia. Discovery Rep., 7:27-138.

1934. Foraminifera, Pt. 3. The Falklands sector of the Antarctic (excluding South Georgia). Discovery Rep., 10:1-208.

1936. Foraminifera, Pt. 4. Additional records from the Weddell Sea sector from material obtained by the S. Y. Scotia. Discovery Rep., 13:1-76.

Echols, R. J., 1971. Distribution of Foraminifera in sediments of the Scotia Sea area, Antarctic waters. In Reid, J. L. (Ed.), Antarctic Oceanology: Am. Geophys. Union Antarct. Res. Ser., 15:93-168.

Ehrmann, W. U., 1991. Sediment composition on Southern Kerguelen Plateau and its implications for paleoclimate and depositional environment. In Barron, J., Larsen, B., et al., Proc. ODP, Sci. Results, 119: College Station, TX (Ocean Drilling Program).

Emery, W. J., and Meincke, J., 1986. Global water masses: summary and review. Oceanol. Acta, 9:383-391.

Foldvik, A., and Gammelsrød, T., 1988. Notes on Southern Ocean hydrography, sea-ice and bottom water formation. Palaeogeogr., Palaeoclimatol., Palaeoecol., 67:3-17.

Foldvik, A., Gammelsrød, T., and Tørresen, T., 1985. Circulation and water masses on the southern Weddell Sea Shelf. Antarct. Res. Ser., 43:5-20.

Foster, T. D., and Middleton, J. H., 1980. Bottom water formation in the western Weddell Sea. Deep-Sea Res., Pt. A, 27:367-381.

Gooday, A. J., 1988. A response by benthic foraminifera to the deposition of phytodetritus in the deep sea. Nature, 332:70-73.

Grobe, H., Mackensen, A., Hubberten, H.-W., Spieß, V., and Fütterer, D. K., 1990. Stable isotope record and late Quaternary sedimentation rates at the Antarctic continental margin. In Bleil, U., and Thiede, J. (Eds.), Geological History of Polar Oceans: Arctic versus Antarctic. NATO/ASI Series C., Dordrecht (Kluwer Academic Publishers), 539-571.

Hambrey, M., Ehrmann, W. U., and Larsen, B., 1991. The Cenozoic glacial record of the Prydz Bay continental shelf, East Antarctica. In Barron, J., Larsen, B., et al., Proc. ODP, Sci. Results, 119: College Station, TX (Ocean Drilling Program).

Hellmer, H., and Bersch, M., 1985. The Southern Ocean: a survey of oceanographic and marine meteorological research work. Ber. Polarforsch., 26:1-115.

Herb, R., 1971. Distribution of Recent benthonic foraminifera in the Drake Passage. Antarc. Res. Ser., 17:251-300.

Heron-Allen, E., and Earland, A., 1932. Foraminifera, Pt. 1. The ice-free areas of the Falkland Islands and adjacent areas. Disc. Repts., 4:291-460.

Keir, R. S., 1988. On the late Pleistocene ocean geochemistry and circulation. Paleoceanography, 3:413-445.

Kurihara, K., and Kennett, J. P., 1988. Bathymetric migration of deep-sea benthic foraminifera in the southwest Pacific during the Neogene. J. Foraminiferal Res., 18:75-83.

Leckie, R. M., and Webb, P.-N., 1986. Late Paleogene and early Neogene foraminifers of Deep Sea Drilling Project Site 270, Ross Sea, Antarctica. In Kennett, J. P., Von der Borch, C. C., et al., Init. Repts. DSDP, 90: Washington (U.S. Govt. Printing Office), $1093-1142$.

Li, Y., and Zhang, Q., 1986. Recent foraminifers from Great Wall Bay, King George Island, Antarctica. Acta Micropaleontol. Sinica, 3:345-349.

Lindenberg, H. G., and Auras, A., 1984. Distribution of arenaceous foraminifera in depth profiles of the Southern Ocean (Kerguelen Plateau Area). Palaeogeogr., Palaeoclimatol., Palaeoecol., 48:61-106.

Lohmann, G. P., 1978. Abyssal benthonic foraminifera as hydrographic indicators in the western South Atlantic Ocean. J. Foraminiferal Res., 8:6-34.

Lutze, G. F., and Coulbourn, W., 1984. Recent benthic foraminifera from the continental margin of northwest Africa: community structure and distribution patterns. Mar. Micropaleontol., 8:361-401.
Lutze, G. F., and Thiel, H., 1987. Cibicidoides wuellerstorfi and Planulina ariminensis, elevated epibenthic foraminifera. In Altenbach, A. V., et al. (Eds.), Beobachtungen an Benthos-Foraminiferen. Report Sonderforschungsbereich 313, Univ. of Kiel, Federal Republic of Germany: 17-30.

Mackensen, A., 1987. Benthische Foraminiferen auf dem Island-Schottland Rücken: Umwelt-Anzeiger an der Grenze zweier ozeanischer Räume. Paläontol. Z., 61:149-179.

Mackensen, A., and Douglas, R. G., 1989. Down-core distribution of live deep-water benthic foraminifera in box cores from the Weddell Sea and the California continental borderland. Deep-Sea Res. Part A, 36:879-900.

Mackensen, A., Grobe, H., Hubberten, H. W., SpieB, V., and Fütterer, D. K., 1989. Stable isotope stratigraphy from the Antarctic continental margin during the last one million years. Mar. Geol., 87:315-321.

Mackensen, A., Grobe, H., Kuhn, G., and Fütterer, D. K., 1990. Benthic foraminiferal assemblages from the eastern Weddell Sea between $68^{\circ}$ and $73^{\circ} \mathrm{S}$ : distribution, ecology and fossilization potential. Mar. Micropaleontol., 16:241-283.

Mackensen, A., and Hald, M., 1988. Cassidulina teretis Tappan and $C$. laevigata d'Orbigny: their living and late Quaternary distribution in northern seas. J. Foraminiferal Res., 18:16-24.

Mackensen, A., Sejrup, H. P., and Jansen, E., 1985. The distribution of living and dead benthic foraminifera on the continental slope and rise off southwest Norway. Mar. Micropaleontol., 9:275-306.

Mead, G. A., 1985. Recent benthic foraminifera in the Polar Front region of the southwest Atlantic. Micropaleontology, 31:221-248.

Mead, G. A., and Kennett, J. P., 1987. The distribution of recent benthic foraminifera in the Polar Front region, southwest Atlantic. Mar. Micropaleontol., 11:343-360.

Milam, R. W., and Anderson, J. B., 1981. Distribution and ecology of Recent benthic foraminifera of the Adelie-George V continental shelf and slope, Antarctica. Mar. Micropaleontol., 6:297-325.

Miller, K. G., and Katz, M. E., 1987. Oligocene to Miocene benthic foraminiferal and abyssal circulation changes in the North Atlantic. Micropaleontology, 33:97-149.

Miller, K. G., and Lohmann, G. P., 1982. Environmental distribution of Recent benthic foraminifera on the northeast United States continental slope. Geol. Soc. Am. Bull., 93:200-206.

Mix, A. C., 1989. Pleistocene paleoproductivity: evidence from organic carbon and foraminifer species. In Berger, W. H., Smetacek, V. S., and Wefer, G. (Eds.), Productivity of the Oceans: Present and Past: New York (Wiley), 313-340.

Olausson, E., 1960. Description of sediment cores from the Mediterranean and the Red Sea. Rep. Swed. Deep-sea Exped. 1947-1948, $8: 287-334$.

Osterman, L. E., and Kellogg, T. B., 1979. Recent benthic foraminifer distributions from the Ross Sea, Antarctica: relation to ecologic and oceanographic conditions. J. Foraminiferal Res., 9:250-269.

Plancke, J., 1977. Phytoplankton biomass and productivity in the subtropical convergence area and shelves of the western Indian subantarctic islands. In Llano, G. A. (Ed.), Adaptations Within Antarctic Ecosystems: Washington (Smithsonian Inst.), 51-73.

Rögl, F., 1976. Late Cretaceous to Pleistocene foraminifera from the Southeast Pacific Basin, DSDP Leg 35. In Hollister, C. D., Craddock, C., et al., Init. Repts. DSDP, 35: Washington (U.S. Govt. Printing Office), 539-555.

Sarnthein, M., Winn, K., Duplessy, J.-C., and Fontugne, M. R., 1988. Global variations of surface ocean productivity in low and mid latitudes: influence on $\mathrm{CO}_{2}$ reservoirs of the deep ocean and atmosphere during the last 21,000 years. Paleoceanography, 3:361-399.

Schlich, R., Coffin, M. F., Munschy, M., Stagg, H.M.J., Li, Z. G., and Revill, K., 1987. Bathymetric Chart of the Kerguelen Plateau. Jointly edited by Bureau of Mineral Resources, Geology and Geophysics, Canberra, Australia; Institut de Physique du Globe, Strasbourg, France; and Terres Australes et Antarctiques Françaises, Paris, France.

Schlich, R., Wise, S. W., Jr., et al., 1989. Proc. ODP, Init Repts., 120: College Station, TX (Ocean Drilling Program).

Schnitker, D., 1980. Quaternary deep sea benthic foraminifers and bottom water masses. Annu. Rev. Earth Planet. Sci., 8:343-370. 
Streeter, S. S., 1972. Living benthonic foraminifera of the Gulf of California, a factor analysis of Phleger's (1964) data. Micropaleontology, 18:64-73.

Thomas, E., 1990. Late Cretaceous through Neogene deep-sea benthic foraminifers (Maud Rise, Weddell Sea, Antarctica). In Barker, P. F., Kennett, J. P., et al., Proc. ODP, Sci. Results, 113: College Station, TX (Ocean Drilling Program), 571-594.

Thomas, E., and Vincent, E., 1987. Equatorial Pacific deep-sea benthic foraminifera: faunal changes before the middle Miocene polar cooling. Geology, 15:1035-1039.

Tjalsma, L., and Lohmann, G., 1983. Paleocene-Eocene bathyal and abyssal benthic foraminifera from the Atlantic Ocean. Micropaleontol., Spec. Publ., 4:1-90.

Uchio, T., 1960. Biological results of the Japanese Antarctic Research Expedition: benthonic foraminifera of the Antarctic Ocean. Seto Mar. Biol. Lab. Spec. Publ., 12:1-21.

Van der Zwaan, G. J., 1982. Quantitative analyses and the reconstruction of benthic foraminifer communities. Utrecht Micropaleontol. Bull., 30:49-69.

van Morkhoven, F.P.C.M., Berggren, W. A., and Edwards, A. S., 1986. Cenozoic cosmopolitan deep-water benthic foraminifera. Bull. Cent. Rech. Explor.-Prod. Elf-Aquitaine, Mem. No. 11.
Whitworth, T., III, 1988. The Antarctic circumpolar current. Oceanus, 31:53-58.

Wiesner, H., 1931. Die Foraminiferen der deutschen Südpolar-Expedition. In von Drygalski, E. (Ed.), Deutsche Südpolar-Expedition, 1901-1903, 20:49-169.

Woodruff, F., 1985. Changes in Miocene deep-sea benthic foraminiferal distribution in the Pacific Ocean: relationship to paleoceanography. In Kennett, J. P. (Ed.), The Miocene Ocean: Paleoceanography and Biogeography. Mem. Geol. Soc. Am., 163:131-175.

Woodruff, F., and Savin, S., 1989. Miocene deep-water oceanography. Paleoceanography, 4:87-140.

Zahn, R., Winn, K., and Sarnthein, M., 1986. Benthic foraminiferal $\delta^{13} \mathrm{C}$ and accumulation rates of organic carbon: Uvigerina peregrina group and Cibicidoides wuellerstorfi. Paleoceanography, $1: 27-42$.

Date of initial receipt: 14 June 1989

Date of acceptance: 20 September 1990

Ms 120B-167 


\section{APPENDIX A}

Reference List of Benthic Foraminifers Used in Principal Component Analyses

Anomalina spp.

Anomalinoides alazanensis $($ Nuttall $)=$ Anomalina alazanensis Nuttall, 1932

Anomalinoides spissiformis (Cushman and Stainforth) $=$ Anomalina alazanensis Nuttall var. spissiformis Cushman and Stainforth, 1945

Anomalinoides semicribratus $($ Beckmann $)=$ Anomalina pompilioides Galloway and Heminway var. semicribrata Beckmann, 1954

Astrononion pusillum Hornibrook, 1961

Bigenerina $\mathrm{cf}$. $\boldsymbol{B}$. nodosaria d'Orbigny

Bolivina huneri Howe, 1939

Bolivina spp.

Bulimina aculeata d'Orbigny, 1826

Bulimina alazanensis Cushman, 1927

Bulimina striata d'Orbigny, 1826

Brizalina sp.

Cassidella bradyi $($ Cushman $)=$ Virgulina bradyi Cushman, 1922

Cassidulina teretis Tappan, 1951

Cassidulina cf. C. havanensis Cushman and Bermudez, 1936

Cibicidoides bradyi (Trauth) = Truncatulina bradyi Trauth, 1918

Cibicidoides cicatricosus (Schwager) $=$ Anomalina cicatricosa Schwager, 1866

Cibicidoides mundulus (Brady, Parker and Jones) $=$ Truncatulina mundula Brady, Parker and Jones, 1888

Cibicidoides pachyderma $($ Rzehak $)=$ Truncatulina pachyderma Rzehak, 1886

Cibicidoides wuellerstorfi (Schwager) $=$ Anomalina wüllerstorfi Schwager, 1866

Cibicidoides spp.

Dentalina spp.

Eggerella bradyi $($ Cushman $)=$ Verneuilina bradyi Cushman, 1911

Ehrenbergina pupa (d'Orbigny) = Cassidulina pupa d'Orbigny, 1839

Ehrenbergina glabra Heron-Allen and Earland = Ehrenbergina hystrix Brady var. glabra Heron-Allen and Earland, 1922

Eponides weddellensis Earland, 1936

Eponides sp.

Epistominella exigua $($ Brady $)=$ Pulvinulina exigua Brady, 1884

Epistominella rugosa (Phleger and Parker) = Pseudoparella? rugosa Phleger and Parker, 1951

Fissurina spp.

Fursenkoina earlandi $(\mathrm{Parr})=$ Bolivina earlandi Parr, 1950

Gavelinopsis lobatulus $($ Parr) $=$ Discorbis lobatulus Parr, 1950

Glandulina sp.

Globocassidulina subglobosa $($ Brady $)=$ Cassidulina subglobosa Brady, 1884

Gyroidina lamarckiana (d'Orbigny) = Rotalina lamarckiana d'Orbigny, 1839

Gyroidinoides soldanii (d'Orbigny) = Gyroidina soldanii d'Orbigny, 1826

Gyroidina sp. small

Gyroidina spp.

Gyroidinoides spp.

Hanzawaia sp.

Heronallennia sp.

Karreriella bradyi (Cushman) = Gaudryina bradyi Cushman, 1911

Karreriella subglabra (Gümbel) = Gaudryina subglabra Gümbel, 1868

Karreriella novangliae $($ Cushman $)=$ Gaudryina baccata var. novangliae Cushman, 1922
Lagena spp.

Laticarinina pauperata (Parker and Jones) $=$ Pulvinulina repanda Fichtel and Moll var. menardii d'Orbigny subvar. pauperata Parker and Jones, 1865

Lenticulina spp.

Martinotiella nodulosa $($ Cushman $)=$ Clavulina nodulosa Cushman, 1922

Martinotiella sp.

Melonis barleeanus (Williamson) $=$ Nonionina barleeana Williamson, 1858

Melonis pompilioides (Fichtel and Moll) $=$ Nautilus pompilioides Fichtel and Moll 1798

Melonis sp.

Miliolinella spp.

Nonion sp. 6

Nonion havanensis Cushman and Bermudez, 1937

Nonionella iridea Heron-Allen and Earland, 1932

Nodosaria spp.

Nonionella bradii $($ Chapman $)=$ Nonionina scapha $($ Fichtel and Moll) var. bradii Chapman, 1916

Nuttallides umbonifera (Cushman) = Pulvinulinella umbonifera Cushman, 1933

Ophthalmidium pusillum (Earland) = Spiroloculina pusilla Earland, 1934

Oridorsalis umbonatus (Reuss) $=$ Rotalina umbonata Reuss, 1851

Orthomorphina spp.

Osangularia culter (Parker and Jones) $=$ Planorbulina culter Parker and Jones, 1865

Planulina renzi Cushman and Stainforth, 1945

Pleurostomella sp.

Psammosphaera fusca Schulze, 1875

Pullenia bulloides (d'Orbigny) $=$ Nonionina bulloides d'Orbigny, 1826

Pullenia simplex (Rhumbler) $=$ Nonionina simplex RhumblerWiesner, 1931

Pullenia subcarinata (d'Orbigny) $=$ Pullenia subcarinata d'Orbigny, 1839

Pyrgo murrhina $($ Schwager $)=$ Biloculina murrhina Schwager, 1866

Pyrgo spp.

Quinqueloculina spp.

Quinqueloculina sp. 3

Rectuvigerina multicostata (Cushman and Jarvis) = Siphogenerina multicostata Cushman and Jarvis, 1929

Reophax nodulosus Brady, 1879

RhabdamminalHyperammina

Siphotextularia spp.

Sphaeroidina bulloides d'Orbigny, 1826

Spiroplectammina cubensis (Cushman and Bermudez) $=$ Spiroplectoides cubensis Cushman and Bermudez, 1937

Stilostomella spp.

Textularia cf. T. wiesneri Earland, 1933

Trifarina angulosa $($ Williamson $)=$ Uvigerina angulosa Williamson, 1858 (including Angulogerina carinata Cushman, 1927; Angulogerina fluens Todd, 1947; and Angulogerina earlandi Parr, 1950)

Triloculina trihedra Loeblich and Tappan, 1953 (including Triloculina frigida Lagoe, 1977)

Uvigerina graciliformis Papp and Turnovsky, 1953

Uvigerina hispida Schwager, 1866

Uvigerina hispido-costata Cushman and Todd, 1945

Uvigerina peregrina Cushman, 1923

Uvigerina proboscidea Schwager, 1866

Uvigerina spp.

Valvulineria laevigata Phleger and Parker, 1951 


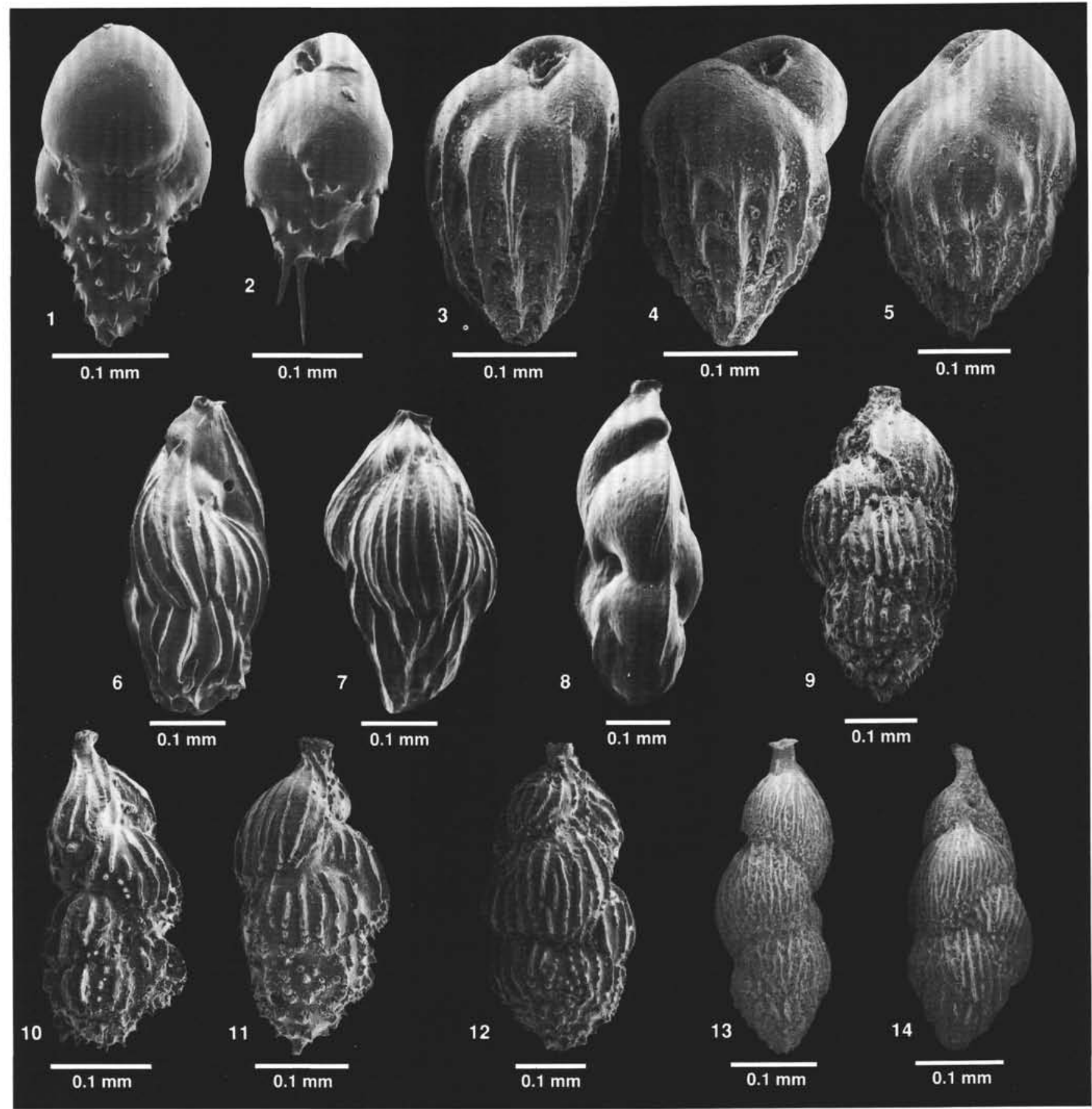

Plate 1. 1-2. Bulimina aculeata d'Orbigny, Sample 120-751A-1H-1, 0-4 cm. 3-4. Bulimina alazanensis Cushman, Sample 120-751A-17H-2, $36-40 \mathrm{~cm}$. 5. Bulimina striata d'Orbigny. Sample $120-751 \mathrm{~A}-17 \mathrm{H}-2,36-40 \mathrm{~cm}$. 6-8. Trifarina angulosa (Williamson), Sample 120-751A-2H-1, 72-76 cm. 9-12. Uvigerina hispidocostata Cushman and Todd, Sample 120-751A-17H-2, $36-40 \mathrm{~cm}$. 13-14. Uvigerina sp., Sample $120-751 \mathrm{~A}-6 \mathrm{H}-3,72-76 \mathrm{~cm}$. 


\section{A. MACKENSEN}

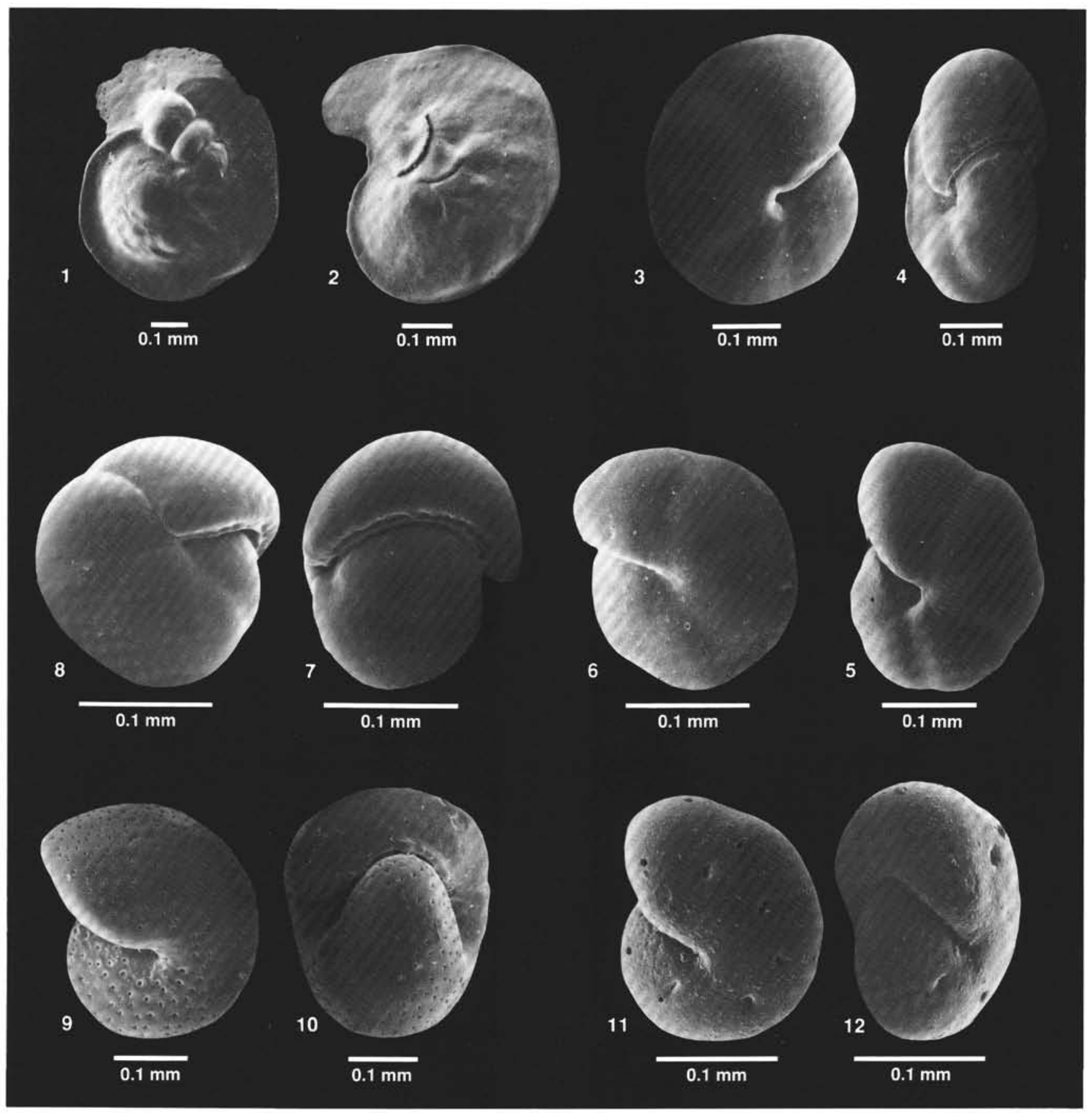

Plate 2. 1-2. Laticarinina pauperata (Parker and Jones), (1) Sample 120-751A-2H-1, 144-148 cm, (2) Sample 120-751A-12H-4, 72-76 cm. 3-5. Pullenia subcarinata (d'Orbigny), (3, 4) Sample 120-751A-2H-1, 144-148 cm, (5) Sample 120-751A-3H-4, 72-76 cm. 6. Pullenia simplex (Rhumbler), Sample 120-751A-2H-1, 144-148 cm. 7-8. Pullenia bulloides (d'Orbigny), Sample 120-751A-1H-1, 0-4 cm. 9-10. Melonis pompilioides (Fichtel and Moll), Sample 120-751A-2H-1, 72-76 cm. 11-12. Astrononion pusillum Hornibrook, Sample 120-751A-6H-3, $72-76 \mathrm{~cm}$. 


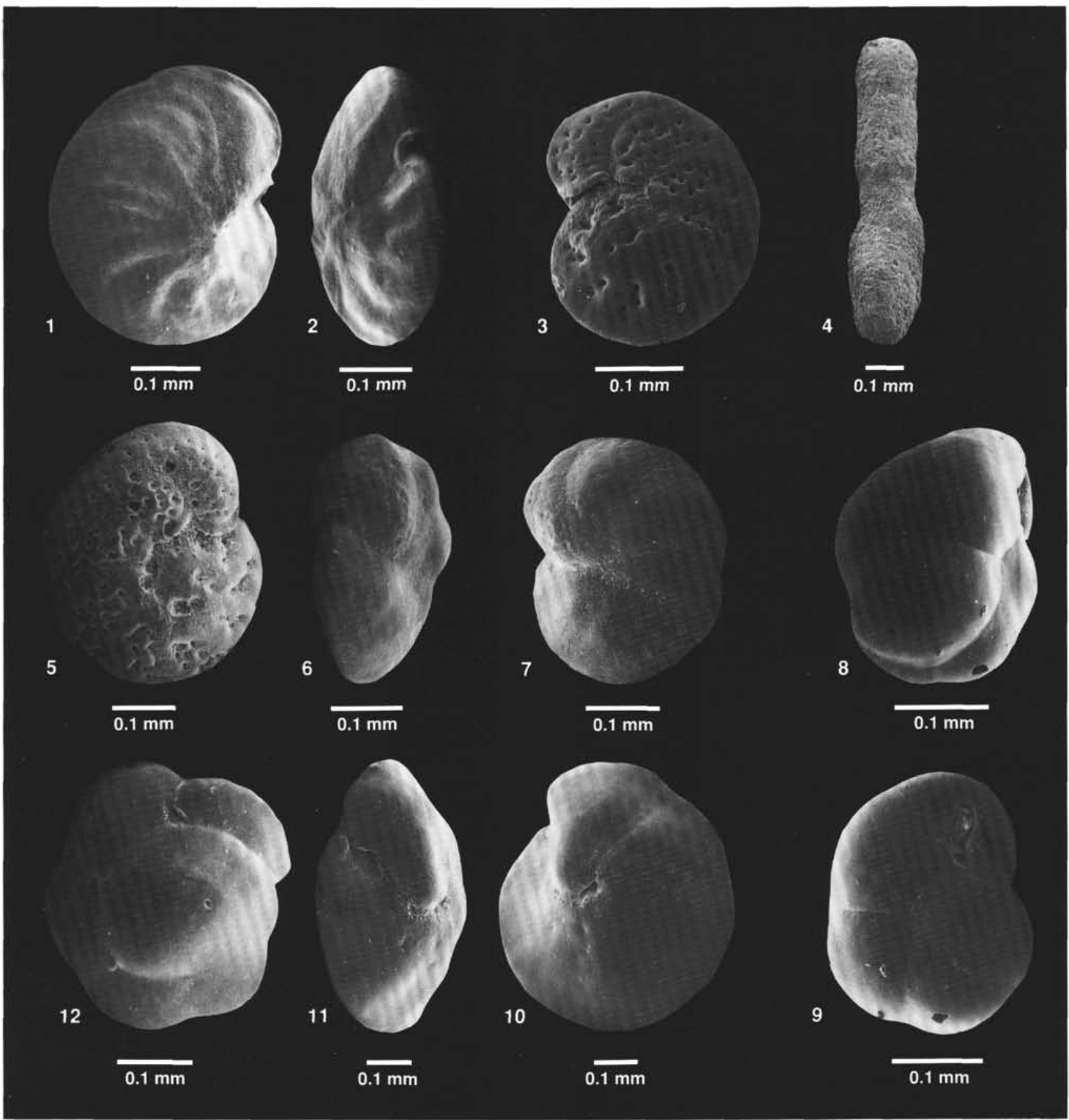

Plate 3. 1-3. Cibicidoides wuellerstorfi (Schwager), (1, 2) Sample 120-751A-1H-1, 0-4 cm, (3) 120-751A-3H-4, 72-76 cm. 4. Martinotiella nodulosa (Cushman), Sample 120-751A-6H-3, 72-76 cm. 5-7. Cibicidoides mundulus (Brady, Parker and Jones), Sample 120-751A-6H-3, $72-76 \mathrm{~cm}$. 8-9. Globocassidulina subglobosa (Brady), Sample 120-751A-2H-1, 72-76 cm. 10-12. Oridorsalis umbonatus (Reuss), Sample $120-751 \mathrm{~A}-2 \mathrm{H}-1,144-148 \mathrm{~cm}$. 


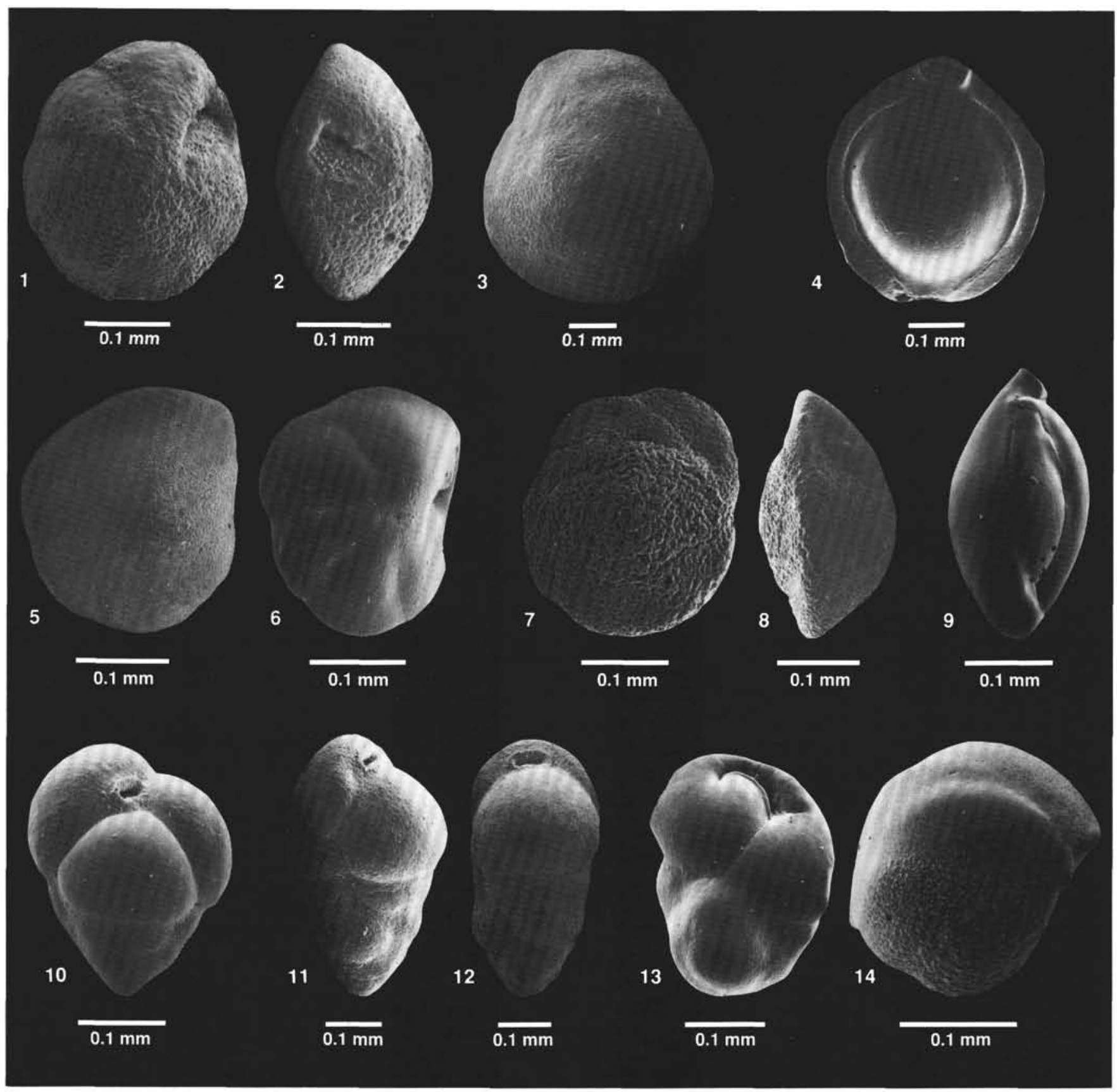

Plate 4. 1-3. Nuttallides umbonifer (Cushman), Sample 120-751A-12H-4, 72-76 cm. 4. Pyrgo murrhina (Schwager), Sample 120-751A-2H-3, 36-40 cm. 5-6. Epistominella exigua (Brady), Sample 120-751A-2H-3, 36-40 cm. 7-8. Epistominella rugosa (Phleger and Parker), Sample 120-751A-12H-4, 72-76 cm. 9. Triloculina trihedra Loeblich and Tappan, Sample 120-751A-1H-1, 0-4 cm. 10. Eggerella bradyi (Cushman), Sample 120-751A-1H-1, 0-4 cm. 11-12. Karreriella bradyi (Cushman), Sample 120-751A-2H-3, 36-40 cm. 13-14. Ehrenbergina glabra Heron-Allen and Earland, Sample 120-751A-1H-1, 0-4 cm. 


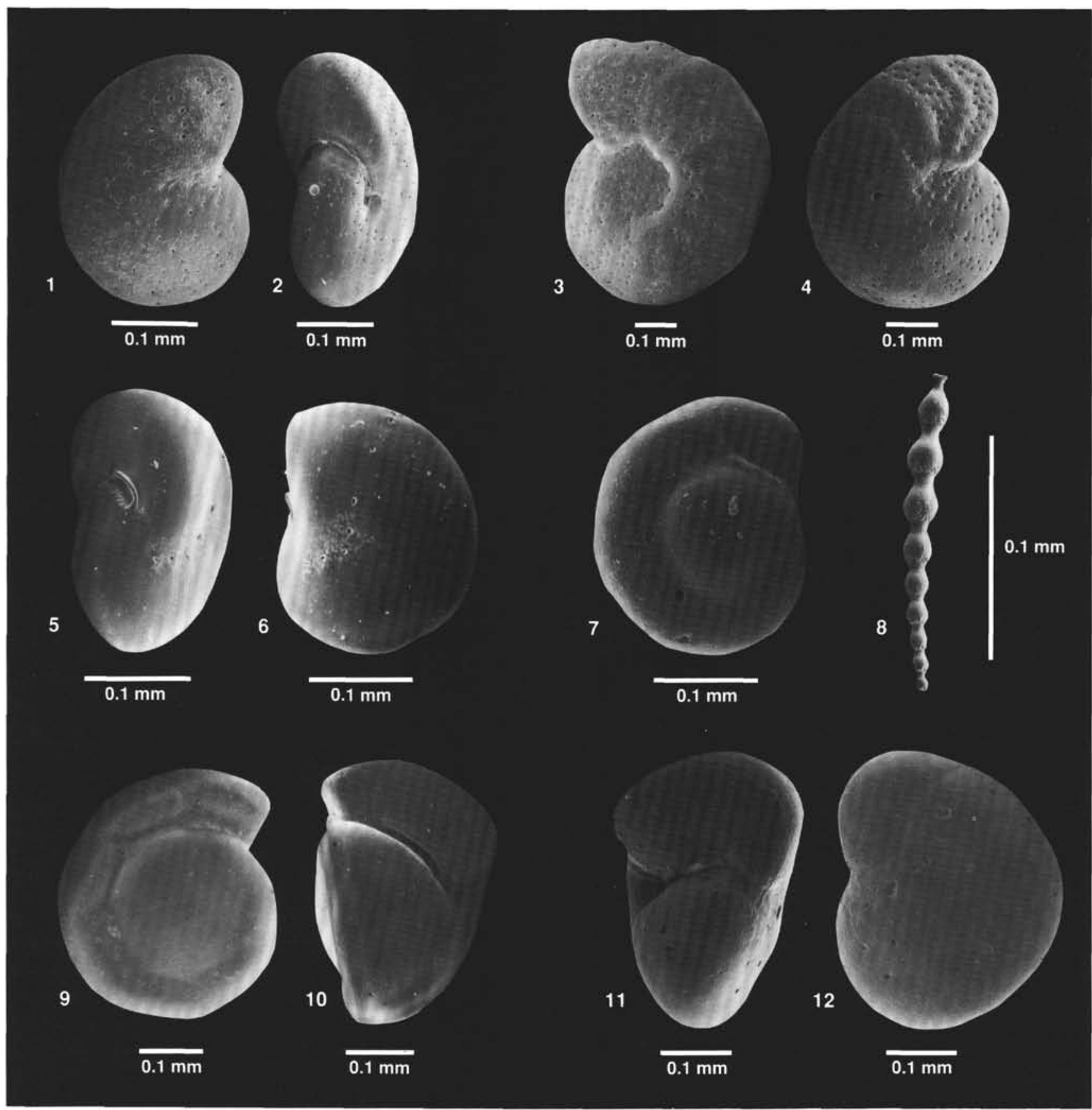

Plate 5. 1. Anomalinoides spissiformis (Cushman and Stainforth), Sample 120-751A-17H-2, 36-40 cm. 2. Melonis barleeanus (Williamson), Sample 120-751A-2H-1, 72-76 cm. 3-4. Anomalinoides alazanensis (Nuttall), Sample 120-751A-17H-2, 36-40 cm. 5-6. Gyroidina sp. BC, Sample 120-751A-1H-1, 0-4 cm. 7. Gyroidinoides sp., Sample 120-751A-6H-3, 72-76 cm. 8. Stilostomella lepidula (Schwager), Sample $120-751 \mathrm{~A}-12 \mathrm{H}-4,72-76 \mathrm{~cm}$. 9-10. Gyroidinoides soldanii d'Orbigny, Sample 120-751A-6H-3, 72-76 cm. 11-12. Gyroidinoides sp., Sample $120-751 \mathrm{~A}-2 \mathrm{H}-3,36-40 \mathrm{~cm}$. 